$\mathcal{S}_{\text {https://doi.org/10.3765/sp.13.11 }}^{\text {Semantics \& Pragmatics Volume 13, Article 11: 1-50, } 2020}$

\title{
Predicting the end: Epistemic change in Romance*
}

\author{
Patrícia Amaral \\ Department of Spanish and \\ Portuguese \\ Indiana University
}

\author{
Fabio Del Prete \\ CLLE-ERSS \\ CNRS et Université de Toulouse II
}

Submitted 2019-06-07 / First decision 2019-11-09 / Revision received 2020-02-26 /

Accepted 2020-07-21 / Published 2020-10-28 / Final typesetting 2022-06-28

\begin{abstract}
This paper analyzes a verbal periphrasis in European Portuguese (EP) and Italian (I), formed by a verb meaning 'to end', a 'by'-preposition and a verb in the infinitive form (V). We show that this periphrasis - for short, [end by V] - behaves differently from the aspectual terminative periphrasis formed with the verb end, by focusing on three semantic criteria. We argue that the meaning of [end by V] involves a specific type of epistemic modality related to expectation. We compare the periphrasis with the discourse particles afinal (EP) and alla fine (I), both etymologically related to a form meaning 'end', which can also express expectation-related modality and have been analyzed as epistemic modal operators sensitive to a temporal succession of epistemic states (Amaral \& Del Prete 2016, 2017). To account for the semantic properties of [end by V], we propose a formal analysis of this periphrasis in which the 'end'-verb, combined with the 'by'-preposition, selects a property of eventualities $P$ as an argument and presupposes the existence of a sequence of events $s \vec{s}$. The periphrasis makes a twofold semantic contribution: (i) it asserts that a $P$-eventuality occurs at the end of the sequence $\vec{s}$, and (ii) it implies that the occurrence of the $P$-eventuality at the end of $s \rightarrow$ is ranked below some alternative outcome on a likelihood/preference scale. We discuss the implications of our analysis for the study of epistemic modality.
\end{abstract}

Keywords: epistemic modality, expectation, event sequences, verbal periphrases, Romance languages

* We thank Kai von Fintel and three anonymous reviewers of Semantics \& Pragmatics for their comments. In addition, for discussion of several empirical and theoretical aspects of this paper we thank Myriam Bras, Bridget Copley, Marta Donazzan, Louise Esher, Jacqueline Guéron, Beth Levin, Jean Sibille, Danilo Sorce, Beppe Spolaore, Jesse Tseng, Sandro Zucchi.

(C)2020 Patrícia Amaral and Fabio Del Prete

This is an open-access article distributed under the terms of a Creative Commons Attribution License (https://creativecommons.org/licenses/by/3.o/). 
Amaral \& Del Prete

\section{Introduction}

In this paper we focus on a Romance verbal periphrasis formed by a verb meaning 'to end' followed by a 'by'-preposition and a verb in the infinitive, henceforth V. The periphrasis, referred to below as [end by V], is exemplified in (1a), for European Portuguese (EP), and (1b), for Italian (I):1,2
a. Depois de uma manhã de sol acabou
por chover. after of a morning of sun end.3SG.PST.IND by rain.INF 'After a sunny morning it ended up raining.'

b. Uno dei migliori giorni della mia carriera finì per One of.the best days of.the my career end.3SG.PST.IND by essere uno dei peggiori.

be.INF one of.the worst

'One of the seemingly best days of my career ended up being one of the worst.'

The [end by V] periphrasis can be seen as a two-way implicative (Karttunen 1971, Nairn, Condoravdi \& Karttunen 2006). Both the implications in (2a)-(2b) from Italian are valid: ${ }^{3}$

(2) a. Rosemary finì per diventare un'assassina. 'Rosemary ended up becoming a killer.'

$\Rightarrow$ Rosemary diventò un'assassina. 'Rosemary became a killer.'

1 We use naturally-occurring examples of the periphrasis in European Portuguese and Italian from the Web. Given that some tests require specific predicates or co-occurrence with specific adverbials, we also use constructed examples. All the examples of the periphrasis are translated with the construction end up $V$-ing, which we think is its closest semantic equivalent in English. However, we do not claim that the analysis we propose for the Romance periphrasis in Section 5 is the correct analysis for the English construction.

2 We adopt the Leipzig Glossing Rules. Abbreviations in glosses throughout the paper are as follows:

$\mathrm{SG}=$ singular, $\mathrm{PL}=$ plural, $\mathrm{l} / 2 / 3=$ first $/$ second $/$ third person, $\mathrm{PRS}=$ present, $\mathrm{IMPF}=$ imperfect, $\mathrm{PST}=$ past, $\mathrm{FUT}=$ future, $\mathrm{IND}=$ indicative, $\mathrm{SBJV}=$ subjunctive, $\mathrm{INF}=$ infinitive, $\mathrm{GER}=$ gerund, $\mathrm{PTCP}=$ participle, $\mathrm{CL}=$ clitic, $\mathrm{LOC}=$ locative, $\mathrm{DAT}=$ dative, SUPER $=$ superlative .

3 The negative sentence ( $2 \mathrm{~b}$ ) sounds odd out of the blue because it is contextually constrained. This sentence is acceptable if uttered as an answer to the Question Under Discussion "Did some person end up becoming a killer?", in a context in which the interlocutors are discussing possible outcomes of some people's development. 
Predicting the end: Epistemic change in Romance

b. Rosemary non finì per diventare un'assassina.

'Rosemary didn't end up becoming a killer.'

$\Rightarrow$ R. non diventò un'assassina.

'R. didn't become a killer.'

As with the polarity implications of the two-way implicative manage, these implications are not cancelable:

(3) a. *Rosemary finì per diventare un'assassina ma non lo diventò veramente.

'Rosemary ended up becoming a killer but she didn't really become one.'

b. *Rosemary non finì per diventare un'assassina ma lo diventò comunque.

'Rosemary didn't end up becoming a killer but she became one (in any case).'

This pattern indicates that [end by V] does not contribute a truth conditional content beyond that of (the proposition obtained by inflecting) V. What is the specific contribution of [end by V] then, distinguishing it from the contribution of V? We show that in European Portuguese and Italian [end by V] has a modal implication, related to the propositional attitude of expectation. For the sentences in (1a)-(1b), the relevant implications are (roughly) as follows:

(4) a. It was unexpected that it would rain.

b. It was unexpected that the day in question of my career would be one of the worst.

We adopt a working definition of expectation as a relation between an agent $x$, a time $t$ and a proposition $p$ from a set of alternative propositions $A L T_{p}=$ $\left\{p, p_{i}, \ldots, p_{n}\right\}$ such that at time $t, x$ considers $p$ to be the "best" proposition in $A L T_{p}$, where each of $p, p_{i}, \ldots, p_{n}$ is a candidate for being true of some time $t^{\prime}$ in the future of $t$. The speaker may not know of which future time $t^{\prime}$ the proposition $p$ may be true; for instance, given the appearance of the sky from the window of my office, I may expect that it will eventually rain this morning, without knowing exactly when the rain will start. The "best" in the above definition is typically understood as "most likely", as in an utterance of I expect that the die will not come up six before the roll of a regular die. There can be an additional implication of a certain outcome being "most desirable", as in an utterance of I expect that he will show me some gratitude 
for my help (the relation between expectations and desires has also been pointed out by Giannakidou \& Mari (2018b)). Expectation is similar to belief in being an epistemic attitude that agents hold toward propositions. What is specific to expectation, however, setting it apart from plain belief, is that it is an epistemic attitude that an agent holds pertaining to a time in the future. ${ }^{4}$ This is expectation in general. For the periphrasis, we have a combination of an expectation and an event sequence: the expectation is about the outcome of the event sequence.

To illustrate the specificity of [end by V], we go through a comparison with the epistemic modal might. Epistemic modal bases have been mostly defined in terms of the propositional attitudes of belief (doxastic modality) and knowledge (epistemic modality in the strict sense): in either case, the modal base comes down to the set of possible worlds compatible with the content of someone's attitude (usually the speaker's). Typically, such modal bases are anchored to the time of evaluation of the modal. Consider (5):

(5) John might be the murderer.

This sentence, as evaluated in a context $C$, receives the truth conditions in (6) (we adopt Hacquard's 2010 event-relative modification of the Kratzerian account: $p$ is the proposition that John is the murderer, $e_{0}$ is Hacquard's attitude (belief) event anchoring the modal base and relates to the speechevent - i.e., $e_{0}$ is an attitude of the speaker of $C$, occurring in the world of $C$ at the time of $C-$ and $f$ is Hacquard's modal base function, assigning to any attitude event the set of propositions representing its content):

$$
\llbracket(5) \rrbracket_{C}=1 \text { iff } \exists w^{\prime}\left[w^{\prime} \in \cap f\left(e_{0}\right) \wedge p\left(w^{\prime}\right)\right]
$$

In prose, sentence (5) is true in context $C$ if and only if there is a possible world compatible with the content of the speaker's attitude $e_{0}$ in which the proposition that John is the murderer is true. To account for the meaning of [end by V] we argue that one needs to assume the following: (a) a sequence of events $s$, (b) an epistemic modal base defined in terms of expectations regarding the outcome of $\vec{s}$, (c) a temporal anchoring of this modal base to a time displaced from the evaluation time. Consider (7) (from Italian):

4 A reviewer asks whether we are assuming that future-oriented forms are by themselves epistemic (along the lines of Giannakidou \& Mari (2018a)). We are not: it is the specific type of epistemic modality that we are concerned with here - the expectation-based modality that is future-oriented. 
Predicting the end: Epistemic change in Romance

(7) Gianni, il nostro rispettabile vicino, finì per essere Gianni the our respectable neighbor end.3SG.PST.IND by be.INF un assassino.

a murderer

'Gianni, our respectable neighbour, ended up becoming a murderer.'

Sentence (7) presupposes that, at the beginning of a sequence of events $\vec{s}$, it was unexpected that $s \rightarrow$ would yield a state of Gianni being a murderer perhaps, there was an expectation that Gianni would keep behaving as a respectable person throughout the relevant span of time - and it asserts that $s \rightarrow$ in fact yielded a state of Gianni being a murderer.

In previous work on epistemic modality, the concept of Truth Persistence (TP) has been proposed to account for the epistemic interpretation of the particle sempre in European Portuguese and Italian (Amaral \& Del Prete 2014), in which sempre intuitively conveys the confirmation of a previously entertained plan or a previously believed proposition, as exemplified in (8):

(8) Context: On Friday I tell you that I plan on going to the movies on Sunday night, on Saturday a doubt is raised about the possibility of my plan, then on Sunday morning I meet you and I want to confirm that I am indeed going to the movies tonight.

Sempre vou ao cinema esta noite. sempre go.1SG.PRS.IND to.the cinema this night 'I'm still going to the movies tonight.'5

The related concept of Truth Unpersistence ( $\sim \mathrm{TP})$ has been proposed to account for the epistemic interpretation of the particles alla fine (I)/afinal (EP) (Amaral \& Del Prete 2016, 2017). These particles convey an epistemic change: a proposition that was either expected or believed to be true at some point in time turns out to be false at a subsequent point in time. This is exemplified in (9), for a future-oriented proposition that was expected to be true on the basis of a plan, and in (10), for a proposition that was believed true on the basis of certain evidence:

5 We do not translate the epistemic particles in the glosses: a translation via always otherwise their closest translation equivalent in English - would be misleading, since always does not allow for a Truth Persistence reading. 
Amaral \& Del Prete

(9) Context: On Friday I tell you that I plan on going to the movies on Sunday night, then on Sunday morning I meet you and I want to tell you that I have decided to go to the opera instead.

Afinal (já) não vou ao cinema esta noite.

afinal already not go.1SG.PRS.IND to.the cinema this night

'In the end I'm no longer going to the movies tonight.'

(10) Context: You and I have so far shared the false belief that Micha is Russian, since we have been misled by his name. Today I see from his passport that he is Ukrainian and I change my previous belief on the basis of the more reliable source of information.

Afinal o Micha não é russo.

afinal the Micha not be.3SG.PRS.IND Russian

'In the end Micha is not Russian.' 6

Amaral and Del Prete have shown that both sempre and alla fine/afinal in examples like (8) and (9)-(10) are epistemic modal operators, taking the whole proposition in their scope (the prejacent) as their argument (cf. van der Auwera \& Ammann 2013). Their work also shows that, unlike better studied epistemic modals (e.g., modal verbs like English might; cf. Condoravdi 2002, von Fintel \& Gillies 2007, 2011, Kratzer 2012), these modal operators encode a change in the epistemic ranking of their prejacent at different points in time. For example, sempre in (8) conveys a change in the ranking of its prejacent $p$ (= that the speaker is going to the movies on Sunday night) over a succession of times $t_{0} \prec t_{1} \prec t_{2}$, whereby $p$ is true in the best worlds at $t_{0}$, uncertain at $t_{1}$ and again true in the best worlds at $t_{2}$. As for afinal, in (9)-(10) it conveys a change in the ranking of $p$ over a succession of times $t_{0} \prec t_{\text {end }}$, whereby $p$ is true in the best worlds at $t_{0}$ and false in the best worlds at $t_{\text {end }}$.

The concepts of TP and $\sim \mathrm{TP}$ are at the intersection of modality, evidentiality, and discourse structure:

(a) they relate to modality as they require that a proposition's truth value be assessed relative to the possible worlds in an epistemic space over a given course of time;

6 An anonymous reviewer suggested that (9)-(10) might be analyzed in terms of change of state, without assuming that afinal is an epistemic modal. Notice, however, that the underlying states are not ontic states in this case: in (9) the underlying state is a state in which the subject has a certain intention to bring about the truth of a proposition, and in (10) it is a state in which the subject is committed to the truth of a proposition. 
Predicting the end: Epistemic change in Romance

(b) they relate to evidentiality as the change of beliefs is triggered by the availability of information from a better type of evidential source, namely the actual unfolding of events; ${ }^{7}$

(c) they relate to discourse structure as expressions that convey them impose constraints on the possible discourse contexts in which they may felicitously occur - in order to grasp the interpretation of those expressions, we must have access to discourse information coming from preceding utterances.

A semantic analysis of expressions conveying TP and $\sim \mathrm{TP}$ requires that we take into account the interactions between these domains. The verbal periphrasis examined in this paper, like the discourse particles alla fine and afinal, conveys $\sim \mathrm{TP}$ and adds events and event sequences to the domains in (a)-(c). We compare this periphrasis with the epistemic particles alla fine and afinal in order to tease apart different ways in which languages can encode the notion of $\sim$ TP. By doing so, we hope to contribute to a better understanding of the encoding of change in expectations across languages. ${ }^{8}$

The structure of the paper is as follows. In Section 2 we compare [end by V] with the aspectual terminative periphrasis containing the same auxiliary verb in Italian and European Portuguese and show that the former does not behave like an aspectual periphrasis (Section 2.1). We then argue that [end by V] presupposes that there is a sequence of events and predicates the property of events denoted by $\mathrm{V}$ of an event occurring at the end of the sequence (Section 2.2). It is then shown that an implication of unexpectedness arises out of the interplay between these components (Section 2.3). Section 3 reviews the literature that has focused on the semantics of this construction

7 Evidentiality pertains to ways in which information is obtained, e.g., by visual experience, hearsay, inference. What we mean here is that the unfolding of events also constitutes a source of evidence and hence can be treated as a way of obtaining information. Crucially, we do not argue that the periphrasis [end by V] is an evidential marker, but rather that its meaning relates to the semantic domain of evidentiality (as has been argued for epistemic modality more generally, cf. Kratzer 2012: pp. 22-23).

8 There are some issues that we leave unaddressed here and whose treatment would be part of a complete account of the properties of the [end by V] periphrasis. One is how to fully analyze this periphrasis syntactically. Second, on the semantic side, it would be fruitful to investigate in detail how the periphrasis interacts with tense. Finally, although we are aware that there are cognate counterparts of [end by V] in other Romance languages, it is not our intention to account for the behavior of those constructions in this paper. Such issues are left for further research. 
in Romance. In Section 4 we compare [end by V] with the particles alla fine and afinal. This comparison will bring to light that there is a crucial semantic difference between the periphrasis and the particles: the former specifically conveys expectation-related modality, whereas the latter convey both beliefrelated modality and expectation-related modality. In Section 5 we provide a formal analysis of [end by V] that accounts for the properties described in Section 2 and posits that the periphrasis contributes two meaning components, a modal presupposition and a factual assertion. We conclude by discussing the implications of our work to studies on epistemic modality and the linguistic encoding of epistemic change.

\section{Semantic properties}

\subsection{Differences with respect to the aspectual terminative periphrasis}

The semantic properties of [end by V] differ from those of the aspectual terminative periphrasis with the same auxiliary verb. We show this through the following diagnostics: (i) the selectional restrictions on the types of events denoted by $\mathrm{V}$ (the main or lexical verb of the periphrasis), (ii) the interaction with temporal adverbials, and (iii) the implication patterns that obtain when the periphrasis is under progressive aspect.

\subsubsection{Selectional restrictions}

The auxiliary verbs of aspectual periphrases, known as "aspectual verbs" or "aspectualizers" (Bertucci 2015; Cunha 1998; Oliveira et al. 2001; Laca 2002, 2004, 2005; cf. Smith's 1991 "super-lexical" verbs), are verbs that take as their argument a predicate of eventualities ${ }^{9} P$ and yield a new predicate of eventualities $P^{\prime}$; where $P$ describes certain events, $P^{\prime}$ describes a specific part of those events, i.e., their initial (inception), medial or final phase (culmination). We can schematically represent the meaning of aspectualizers as follows (taking $\mathrm{E}$ as the semantic type of eventualities):

$$
\llbracket \text { aspectualizer } \rrbracket=\lambda P_{\langle\mathrm{E}, \mathrm{t}\rangle}: C(P) \cdot \lambda e \cdot \exists e^{\prime}\left[P\left(e^{\prime}\right) \wedge \mathrm{X}-\mathrm{Phase}\left(e, e^{\prime}\right)\right]
$$

The schematic relational predicate "X-Phase" can take the values Initial, Medial or Final Phase, and the schematic formula $C(P)$ is a (possibly empty)

9 As is standard in the semantics literature (following Bach 1981), we use the term eventuality as a cover term that applies to both events (telic or atelic) and states. 
Predicting the end: Epistemic change in Romance

domain condition, specifying a property that the $P$-argument of the aspectualizer's semantic denotation must satisfy for this function to be defined.

Aspectualizers show selectional restrictions with respect to the aspectual class (Aktionsart) of their V complements. We follow Bertucci (2011) in assuming that the aspectualizer of the terminative periphrasis (terminar de $V$ in Portuguese, which is a variant of acabar de $V$ ) requires an accomplishment $\mathrm{V}$ and yields the final phase of the $\mathrm{V}$-event. This selectional property is exemplified by the pattern in (12a)-(12d) for Portuguese; the periphrasis is only compatible with accomplishment Vs, as in (12a):
a. O João terminou de escrever o artigo. the João finish.3SG.PST.IND of write.INF the article 'João finished writing the article.'
b.??O João terminou de morrer. the João finish.3SG.PST.IND of die.INF 'João finished dying.'
c. ??O João terminou de ser inteligente. the João finish.3SG.PST.IND of be.INF intelligent 'João finished being intelligent.'
d.??O João terminou de ser meu vizinho. the João finish.3SG.PST.IND of be.INF my neighbor 'João finished being my neighbor.'

As Bertucci (2015) points out, this aspectual restriction on $\mathrm{V}$ follows from the semantics of terminar, which we can represent as the following instantiation of (11):

$$
\begin{aligned}
& \text { (13) } \llbracket \text { terminar } \rrbracket=\lambda P_{\langle\mathrm{E}, \mathrm{t}\rangle}: \operatorname{ACCOMPLISHMENT}(P) \cdot \lambda e \cdot \exists e^{\prime}\left[P\left(e^{\prime}\right)\right. \\
& \left.\wedge \operatorname{Final}-\operatorname{Phase}\left(e, e^{\prime}\right)\right]
\end{aligned}
$$

Thus, the terminative aspectualizer takes an event property $P$ (denoted by its VP complement) as argument and, provided that $P$ is of an aspectual type guaranteeing the existence of a final phase, it yields a distinct event property $P^{\prime}$ that is true of an event $e$ if and only if $e$ coincides with the final phase of some $P$-event.

Since the VP escrever o artigo 'to write the article' denotes an event property true of events with a final phase (Bertucci 2011, Rothstein 2004), in (12a) the semantic denotation of terminar can combine with it, yielding the event property in (14a) below. The latter in turn combines with the denotation of 
the subject $o$ João via the agent thematic relation and then with the past tense's denotation to yield the truth conditions in (14b): ${ }^{10}$

(14) a. $\llbracket$ terminar de escrever o artigo $\rrbracket=\llbracket$ terminar $\rrbracket(\llbracket$ escrever o artigo $\rrbracket)$ $=\lambda P_{\langle\mathrm{E}, \mathrm{t}\rangle}: \operatorname{ACCOMPLISHMENT}(P) . \lambda e \cdot \exists e^{\prime}\left[P\left(e^{\prime}\right) \wedge\right.$ Final-Phase $\left.\left(e, e^{\prime}\right)\right]$ $(\lambda e . W R I T E(e) \wedge \operatorname{THEME}(e)=$ the-article $)$ $=\lambda e . \exists e^{\prime}\left[W R I T E\left(e^{\prime}\right) \wedge \operatorname{THEME}\left(e^{\prime}\right)=\right.$ the-article $\wedge$ Final-Phase $\left.\left(e, e^{\prime}\right)\right]$

b. $\llbracket(12 \mathrm{a}) \rrbracket=1$ iff $\exists e\left[e \prec \operatorname{now} \wedge \exists e^{\prime}\left[W \operatorname{RITE}\left(e^{\prime}\right) \wedge \operatorname{THEME}\left(e^{\prime}\right)=\right.\right.$ the-article $\wedge$ Final-Phase $\left.\left(e, e^{\prime}\right)\right] \wedge \operatorname{AGENT}(e)=$ João]

According to (14b), (12a) is true at the condition that there is a past event $e$ that is the final phase of an event of writing the article and the agent of $e$ is João. Notice that João is understood as being the agent of only the final phase of the event of writing the article - a property of (12a) we will come back to shortly. ${ }^{11}$

On the other hand, both achievements, as in (12b), and states (whether permanent, like ser inteligente 'to be intelligent', or temporary, like ser meu vizinho 'to be my neighbor'), as in (12c)-(12d), denote event properties true of eventualities with no inner phases. Therefore, the aspectualizer's denotation cannot combine with the denotation of the VP complement in (12b)-(12d), predicting the unacceptability of those examples.

This behavior of the aspectual terminative periphrasis contrasts with the behavior of [end by V]. The latter is compatible with accomplishments,

10 To compute the truth conditions in (14b) we make use of the following interpretations for the agent thematic relation and the past tense:

(i) $\quad \llbracket$ agent $\rrbracket=\lambda x_{\mathrm{e}} \cdot \lambda P_{\langle\mathrm{E}, \mathrm{t}\rangle} \cdot \lambda e_{\mathrm{E} \cdot}[P(e) \wedge \operatorname{AGENT}(e)=x]$

(ii) $\llbracket \mathrm{PAST} \rrbracket=\lambda P_{\langle\mathrm{E}, \mathrm{t}\rangle} . \exists e[e \prec$ now $\wedge P(e)]$.

11 That the subject of the terminative periphrasis may not be the agent of the (whole) V-event can clearly be seen in examples like (i) (from Italian):

(i) Jacobello da Messina terminò di dipingere la Madonna col Bambino (lasciata incompiuta dal padre Antonello).

'Jacobello da Messina finished painting the Madonna col Bambino (left unfinished by his father Antonello).'

We can truthfully utter (i) knowing that Antonello da Messina was the agent of the initial and medial phases of the event of painting the Madonna col Bambino, while Jacobello only completed the final phase. 
Predicting the end: Epistemic change in Romance

achievements, and even with some states, as shown in (15a)-(15d) (from European Portuguese):

(15) a. O João acabou por escrever o artigo. the João end.3SG.PST.IND by write.INF the article 'João ended up writing the article.'

b. O João acabou por morrer. the João end.3SG.PST.IND by die.INF 'João ended up dying.'

c. ??O João acabou por ser inteligente. the João end.3SG.PST.IND by be.INF intelligent 'João ended up being intelligent.'

d. O João acabou por ser meu vizinho. the João end.3SG.PST.IND by be.INF my neighbor 'João ended up becoming my neighbor.'

In contrast with the agentive property of (12a) noted above, the subject o João in (15a) is understood as being the agent of the (whole) V-event of writing the article, which provides another difference between [end by V] and the terminative periphrasis. Sentences (15c)-(15d) both involve a stative V: (15c), with the permanent state predicate ser inteligente, is unacceptable, but (15d), with the temporary state predicate ser meu vizinho, is acceptable - notice that this predicate appears to be coerced to the interpretation 'to become my neighbor.'

The conclusion is that [end by V], unlike the aspectual terminative periphrasis, does not denote the final phase of a V-eventuality (eventualities in the denotation of $\mathrm{V}$ need not even be events with inner phases).

\subsubsection{Interaction with temporal adverbials}

The aspectual periphrasis in (16) denotes the final phase of the event of reading the book, and this phase is located at $3 \mathrm{PM}$ via the temporal adverbial às 3 horas 'at 3 PM':

Acabei de ler o livro às 3 horas. end.1SG.PST.IND to read.INF the book at.the 3 hours

'I finished reading the book at 3PM.'

Assuming that the verb acabar in this sentence has the same semantics as the aspectualizer terminar defined in (13) above, we derive the interpretation 
in (17a) for the aspectually modified predicate acabar de ler o livro. Assuming further that the time adverbial às 3 horas modifies the latter predicate and locates the final phase of the book reading in time, we derive the truth conditions of (16) in (17b): ${ }^{12}$

$$
\begin{aligned}
\text { a. } \quad \llbracket \text { acabar de ler o livro } \rrbracket=\llbracket \text { acabar } \rrbracket(\llbracket \text { ler o livro } \rrbracket) \\
=\lambda P_{\langle\mathrm{E}, \mathrm{t}\rangle}: \operatorname{ACCOMPLSHMENT}(P) . \lambda e . \exists e^{\prime}\left[P\left(e^{\prime}\right) \wedge \text { Final-Phase }\left(e, e^{\prime}\right)\right] \\
(\lambda e \cdot R E A D(e) \wedge \operatorname{THEME}(e)=\text { the-book }) \\
=\lambda e . \exists e^{\prime}\left[R E A D\left(e^{\prime}\right) \wedge \operatorname{THEME}\left(e^{\prime}\right)=\text { the-book } \wedge \text { Final-Phase }\left(e, e^{\prime}\right)\right] \\
\text { b. } \llbracket(16) \rrbracket=1 \text { iff } \exists e\left[e \prec \operatorname { n o w } \wedge \exists e ^ { \prime } \left[R E A D\left(e^{\prime}\right) \wedge \operatorname{THEME}\left(e^{\prime}\right)=\right.\right.\text { the-book } \\
\left.\left.\quad \wedge \text { Final-Phase }\left(e, e^{\prime}\right)\right] \wedge A T(3 \mathrm{PM})(e) \wedge \operatorname{AGENT}(e)=\text { the-speaker }\right]
\end{aligned}
$$

According to $(17 \mathrm{~b}),(16)$ is true at the condition that there is a past event $e$ that is the final phase of an event of reading the book and the agent of $e$ is the person uttering (16) and $e$ is located at $3 \mathrm{PM}$.

As we turn to [end by V], we see that the effect of the interaction between this periphrasis and the time adverbial in the minimally different sentence (18) is not to locate some phase of the event of reading the book at 3PM:

Acabei por ler 0 livro às 3 horas.

end.1SG.PST.IND by read.INF the book at.the 3 hours

'I ended up reading the book at 3PM.'

While (16) implies that the event of reading the book had started before $3 \mathrm{PM}$, (18) implies that this event started at 3 PM. Notice that this inchoative implication of (18) is only a pragmatic inference and is not part of the semantic content of the sentence: this sentence intuitively means that the event of reading the book did not take place at the time that was planned or expected, but rather at $3 \mathrm{PM}$.

We conclude that [end by V] does not interact with temporal adverbials in the same way as the terminative periphrasis does.

12 To compute the truth conditions in (17b) we make use of the following interpretation for the temporal adverbial:

(i) $\llbracket$ às 3 horas $\rrbracket=\lambda P_{\langle\mathrm{E}, \mathrm{t}\rangle} \cdot \lambda e_{\mathrm{E}} \cdot[P(e) \wedge \mathrm{AT}(3 \mathrm{PM})(e)]$ 
Predicting the end: Epistemic change in Romance

\subsubsection{Implication patterns under progressive aspect}

The periphrasis [end by V] and the aspectual terminative periphrasis also differ in their implication patterns under progressive aspect. Consider (19) and (20), from Italian:

$\begin{array}{lll}\text { Chi ha } & \text { perso la prima casa, } \\ \text { who have.3SG.PRS.IND loose.PST.PTCP the first house }\end{array}$
ha avuto o sta finendo di have.3SG.PRS.IND have.PST.PTCP or stay.3SG.PRS.IND end.GER of avere rimborsi pari al 75 per cento delle spese have.INF reimbursements equal at.the 75 per cent of.the expenses documentate. documented 'Those who have lost their first house have got or are finishing getting reimbursements equal to 75 percent of the documented expenses.'

(20) L' emergenza rifiuti a Napoli sta finendo per the emergency garbage at Naples stay.3SG.PRS.IND end.GER by avere pesanti ripercussioni su tutto il Paese. have.INF heavy repercussions on all the country 'The garbage emergency in Naples is ending up having heavy repercussions on the whole country.'

Sentence (19), with the terminative periphrasis under progressive aspect, entails that people who have lost their first house (and have not already been refunded at the maximum level) have started being refunded, i.e., some refunding has already taken place, and the completion of the event of getting the maximum reimbursement is close. On the other hand, sentence (20), with [end by V] under the progressive, does not entail that Naples' garbage emergency has started having heavy repercussions on the whole country. Rather, this sentence entails that the beginning of the event of having heavy repercussions on the whole country is close or imminent.

The data in (19) and (20) provide further evidence that [end by V] differs semantically from the aspectual terminative periphrasis: while the periphrasis in (19) contributes the final part of an event (the event of getting reimbursements equal to 75 percent of the documented expenses), the periphrasis in (20) contributes an event that is presented as the outcome of several events. 
Amaral \& Del Prete

\subsection{Event sequences}

Although [end by V] does not denote the final phase of a V-event, its interpretation involves the end of a sequence of events. This sequence of events is different from the V-event and does not belong to the realm of lexical aspect, i.e., it does not pertain to "properties we can ascribe to event types in the denotation of particular lexical items" ((Rothstein 2004: p. 2)). For this reason, in order to interpret an utterance such as acabei por ler um livro 'I ended up reading a book', it is not enough to have access to the lexical semantics of the predicate ler um livro 'to read a book'. This is in contrast with the interpretation of the aspectual periphrasis acabei de ler um livro 'I finished reading a book', for which it is enough to have access to the lexical semantics of ler um livro. We will see below that the event sequence underlying the interpretation of [end by V] is identified on the basis of discourse information.

Evidence for the presence of an event sequence comes from examples in which [end by V] co-occurs with a periphrasis built with an antonym of the 'end'-verb. Sentence (21) (from Italian) exemplifies this pattern:

Tom Dixon, poliedrico designer che ha iniziato Tom Dixon polyhedric designer who have.3SG.PRS.IND begin.PTCP con il recupero di rottami e ha finito per with the recovery of scrap and have.3SG.PRS.IND finish.PTCP by diventare direttore artistico di Habitat, una delle più grandi become.INF director artistic of Habitat one of.the more big aziende di arredamento britanniche ha da poco factories of furniture British have.3SG.PRS.IND since little aperto un profilo Facebook ed è attivissimo su open.PTCP a profile Facebook and be.3SG.PRS.IND active.SUPER on Instagram.

Instagram

'Tom Dixon, a versatile designer who started with scrap recovery and ended up becoming the artistic director of Habitat, one of the biggest furniture companies in the UK, has just created a Facebook page and is very active on Instagram.'

Here, the 'start'-periphrasis (ha iniziato con il recupero di rottami) and [end by V] intuitively operate on the same sequence of events, which is salient in the discourse. This sequence can be identified as that part of T.D.'s profes- 
Predicting the end: Epistemic change in Romance

sional career extending from T.D.'s professional start to the time at which (21) is uttered. The 'start'-periphrasis situates scrap recovery at the beginning of this stretch of career and [end by V] situates T.D. as artistic director of Habitat at the end of it. The fact that the sequence of events has a temporal duration, allowing for the specification of the initial time and the final time, underlies the temporal aspects of the interpretation of [end by V].

Sentence (21) provides enough information to allow the hearer to retrieve the event sequence. However, examples (22a)-(22b) would be difficult to make sense of without contextual information about the sequence:

$$
\begin{aligned}
& \text { a. Acabei por ir ao cinema. } \\
& \text { end.1SG.PST.IND by go.INF to.the cinema } \\
& \text { 'I ended up going to the movies.' } \\
& \text { b. Acabou por chover. } \\
& \text { end.3SG.PST.IND by rain.INF } \\
& \text { 'It ended up raining.' }
\end{aligned}
$$

In particular, (22a)-(22b) would be infelicitous in response to neutral questions like $O$ que fizeste ontem? 'What did you do yesterday?' and Como esteve o tempo ontem? 'How was the weather yesterday?'. In order to answer these questions, one would rather use the plain inflected forms of V fui ao cinema 'I went to the movies' and choveu 'it rained.' Sentence (22a) does not just convey that I went to the movies, and (22b) does not just convey that it rained: the fact that I went to the movies and the fact that it rained are presented as outcomes of relevant event sequences.

We propose that the existence of an event sequence is a presupposition of [end by V] and hence the event sequence can be bound by a quantificational expression occurring in the sentence. Evidence for this comes from sentences with a quantificational time adverb scoping above the periphrasis, as in (23):

(23) Sempre que o Pedro tem que tomar uma decisão, always that the Pedro have.3SG.PRS.IND that take.INF a decision acaba por escolher mal. end.3SG.PRS.IND by choose.INF badly

'Every time Pedro has to make a decision, he ends up choosing badly.'

The meaning of (23) can be paraphrased as 'on every occasion in which Pedro has to make a decision, there is a sequence of events in which he engages that ends with an eventuality of Pedro choosing badly (and Pedro's actual choice 
on this occasion is ranked lower than other possible choices he might have made).' In other words, the interpretation obtained is that in each decisionmaking instance, there is a different event sequence, leading to a (different) bad decision.

Once the presupposition of existence of an event sequence is satisfied, [end by V] asserts that a V-eventuality occurs at the end of the event sequence. We propose that [end by V] takes one argument, a property of eventualities $P$, denoted by $\mathrm{V}$. This must be a property true either of events or of states that may be felicitously located in time (that is, it must be possible to situate such a state temporally with respect to the sequence of events). This restriction is shown by the contrast of acceptability between (24a) and (24b):

$$
\begin{aligned}
& \text { a. ??A mulher acabou por ter olhos azuis. } \\
& \text { the woman end.3SG.PST.IND by have.INF eyes blue } \\
& \text { 'The woman ended up having blue eyes.' } \\
& \text { b. Acabou por estar calor. } \\
& \text { end.3SG.PST.IND by be.INF warm } \\
& \text { 'It ended up being/becoming warm.' }
\end{aligned}
$$

On the one hand, to have blue eyes describes states that typically hold of an individual irrespective of the time, as is suggested by the oddity of the temporal specification in the woman had blue eyes on Monday (Magri 2009). On the other hand, to be warm describes states that can be felicitously located in a specific time interval. This distinction between two sorts of states is relevant to account for which V-predicates may occur in the periphrasis. The requirement that the V-eventuality may be located in time will be discussed below, as we consider the differences between the periphrasis and the epistemic particles afinal/alla fine.

Crucially, [end by V] does not just introduce the V-event as the final one in a temporal succession of events; it also implies that this outcome was below

13 Kai von Fintel has pointed out (p.c.) that example (i) is acceptable in English, where the sentence following but is paraphrasable as she turned out to have blue eyes.

(i) I was told she had brown eyes, but she ended up having blue eyes.

As far as we can tell, neither EP acabar por $V$ nor Italian finire per $V$ allow for a reading corresponding to English 'turn out to V'. For instance, the Italian counterpart of (24a) ( $\mathrm{La}$ donna fini per avere occhi azzurri) is not acceptable and cannot be understood as meaning that the woman turned out to have blue eyes. 
Predicting the end: Epistemic change in Romance

some expected value. This modal implication of the periphrasis explains the oddity of the italicized sentence in (25):

(25) ??La giornata è stata fantastica: la mattina the day be.3SG.PRS.IND be.PTCP fantastic the morning

siamo stati al parco, poi abbiamo

be.1PL.PRS.IND be.PTCP at.the park then have.1PL.PRS.IND

pranzato da Gigi e siamo andati a vedere il film

lunch.PTCP at Gigi and be.1PL.PRS.IND go.PTCP to see.INF the movie

su Renzo Piano e la sera abbiamo finito per

on Renzo Piano and the evening have.1PL.PRS.IND end.PTCP by

cenare da Maria.

dine.INF at Maria

'The day was fantastic: in the morning we were at the park, then we had lunch at Gigi's and went to see the movie about Renzo Piano, and in the evening we ended up having dinner at Maria's.'

This discourse describes the succession of events in a certain day. If the final event of this series (the event of the speaker having dinner at Maria's) is introduced by using [end by V], the result is infelicitous. The periphrasis implies that there was some expectation of an alternative outcome but nothing in (25) indicates that any such expectation existed - in this respect, (25) can be described as "epistemically neutral." In the same context, the different verbal construction finire con 'finish with' + eventive DP could have been used felicitously, as in (26):

... e la sera abbiamo finito con una cena

$\ldots$ and the evening have.1PL.PRS.IND end.PTCP with a dinner indimenticabile da Maria.

unforgettable at Maria

' $\ldots$ and in the evening we finished with an unforgettable dinner at Maria's.'

Finire con in (26) relies on a temporal succession of events without triggering epistemic implications.

As we discuss next, the sentences containing the periphrasis not only presuppose an event sequence but also imply that the outcome of that sequence was below some expected value. For example, in (22a) above the speaker had a plan to do something different than going to the movies, compared to which going to the movies appeared as less likely, and in (22b) above the speaker 
expected some alternative weather condition, compared to which rain was less likely. We will now analyze this modal implication in detail.

\subsection{Expectation-based modality}

The modality characterizing [end by V] is expectation-based. The meaning of unexpectedness that the periphrasis conveys arises out of the interplay of two components: (i) the presupposition that there was an expectation regarding the outcome of an event sequence, and (ii) the factual assertion that a V-eventuality occurred, where the final occurrence of the V-eventuality defeats that expectation. For example, the two meaning components in which we analyze Acabou por chover 'It ended up raining' $(=(22 \mathrm{~b}))$ are represented by (p) and (a):

(p) Other things being equal, the occurrence of rain was considered less likely than no-rain.

(Modal presupposition)

(a) It rained.

(Factual assertion)

The expectation-based modality is present here at the level of presupposed content. As shown below, the content of the expectation need not logically contradict the factual assertion of the V-eventuality; it could be that a Veventuality occurring at the end of the event sequence was just unlikely given the expectation. We will incorporate this point as a ranking on the set of propositions corresponding to the expectation state in the lexical entry of the periphrasis in Section 5 .

Not all the instances of [end by V] involve a conscious, concrete expectation. In some examples, $\mathrm{V}$ may describe something contrary to what is assumed to be normal (the normal finalization of an event, the normal time that some task typically takes, etc.). Hence the outcome of a sequence of events in some instances is unforeseen, but not necessarily the contrary of a concrete expectation. One such example is the EP sentence (27):

(27) Caminhámos durante muitíssimo tempo mas acabámos walk.1PL.PST.IND for much.SUPER time but end.1PL.PST.IND por chegar.

by arrive.INF

'We walked for a very long time but we ended up getting there.' (EP) 
Predicting the end: Epistemic change in Romance

In (27), the first conjunct invites a conversational inference to the effect that it would take a long time to arrive at destination and the arrival would even seem unlikely (the persons walking might have wondered: Will we ever get there?). The second conjunct conveys the information that, despite those doubts, the persons did arrive. More explicitly, the proposition that we arrive at place $X$ at time $t_{1}$ (where $X$ is the destination and $t_{1}$ is the relevant time) was not expected at time $t_{0}$, where $t_{0}$ is the initial time of the relevant event sequence - maybe a time midway at which the persons began to believe that an arrival was unlikely. In examples like (27), it is unclear whether the speaker has necessarily expressed this expectation or this is a general assumption that can be inferred from context, in similar situations.

Additionally, the periphrasis is not felicitous if it introduces the last event in a sequence of events that unfolds as expected. If this were the case, (28) should be felicitous, but it is not.

$$
\begin{aligned}
& \text { ??A Maria tinha planeado ir de carro a Veneza } \\
& \text { the Maria have.3SG.IMPF.IND plan.PTCP go.INF by train to Venice } \\
& \text { e acabou por ir de carro. } \\
& \text { and end.3SG.PST.IND by go.INF by car } \\
& \text { 'Maria had planned on going to Venice by car and she ended up going } \\
& \text { there by car.' }
\end{aligned}
$$

The contrast displayed by these examples shows that the periphrasis is not felicitous if the last event of a sequence ${ }^{14}$ confirms a previously entertained plan or expectation. We will return to this issue in (33) below; we will see that a planned outcome is only compatible with the periphrasis if a different perspective is introduced.

We can further probe the meaning of the periphrasis by observing its co-occurrence with other modal expressions, as in (29) and (30) (from EP):

14 An anonymous reviewer asks whether a time interval could accomplish the same function as the event sequence in the analysis of the periphrasis. As can be seen in the examples in this section, the expectation is about the unfolding of a sequence of events and its culmination, regardless of the specific point in time at which it occurs. While it is true that an event sequence determines a time interval, the sequence is not replaceable by the interval: expectations are inherently about the progress of an event sequence toward a (predicted) outcome, while it does not make sense to talk of expectations for a time interval, since time intervals do not unfold or progress toward an outcome. Therefore, the event sequence in our analysis is not there just to provide a time interval for [end by V] to select a time point at the end of it, but for a more substantial reason: the expectation requires it, since the expectation is inherently about the progress of an event sequence. 
Amaral \& Del Prete

(29) Pensava- se que provavelmente eles iam

think.3SG.IMPF.IND CL that probably they go.3PL.IMPF.IND

ler o livro, mas acabaram por ler a revista.

read.INF the book but end.3PL.PST.IND by read.INF the journal

'We thought that they were probably going to read the book, but they ended up reading the journal.'

(EP)

(30) Houve uma grande probabilidade de céu limpo mas

have.3SG.PST.IND a great probability of sky clear but

acabou por chover.

end.3SG.PST.IND by rain.INF

'There was a high probability that the sky would be clear, but it ended up raining.'

The modal expressions pensava-se que provavelmente 'it was thought probable that' and houve uma grande probabilidade 'there was a high probability'15 interact with [end by V] in (29) and (30). The expressions in question introduce an event whose future occurrence is presented as most likely. The contribution of [end by V] is to introduce an unexpected event described by $\mathrm{V}$, i.e., an event of the relevant people reading the journal in (29) and an event of raining in (30).

We should point out that a change in probability value is not enough to license the use of the periphrasis. Consider the following scenario. Manuela suffers from numbness in her hands, so she decides to throw a dice consecutively for ten times as a way to move her hand muscles. At the last throw she gets a 6 . In this context, Manuela could not utter (31) felicitously:

(31) ??Acabou por sair um 6.

'It ended up being a 6.'

The periphrasis is not felicitous because in the context above the speaker did not entertain any expectation about the result of the throw. In order for the periphrasis to be acceptable, there has to be an epistemic agent in the context who assigns a ranking to the V-proposition and some relevant alternatives. By the same token, in (32) the periphrasis is infelicitous because there is no information about a possible expectation and the existence of

15 This probe leads to a testable hypothesis: the periphrasis [end by V] should occur more frequently in the context of probability-related expressions than the aspectual terminative periphrasis (assuming an approach like Distributional Semantics, cf. Harris 1954, Turney \& Pantel 2010). We leave such a quantitative study for further work. 
Predicting the end: Epistemic change in Romance

multiple equiprobable possibilities in the context is not enough to license the felicitous use of [end by V]:

(32) ??Il team di biologi del San Raffaele ha fatto l'esperimento. Il risultato avrebbe potuto essere sia A che B che C (i biologi non si aspettavano nessuno di questi tre come più probabile), ma ha finito per essere osservato $\mathrm{C}$.

'The team of biologists from San Raffaele has conducted the experiment. The result could have been A, B, or C (the biologists did not expect any of these three as more probable), but it has ended up being C.'

The example is not felicitous because none of the possible outcomes (A, B or C) was more or less expected to happen. ${ }^{16}$ The periphrasis is acceptable when the proposition that holds true at the end of the event sequence is ranked lower than some expected alternative according to some agent, an aspect we incorporate in the formal analysis in Section 5.1 as a modal presupposition.

We conclude that [end by V] conveys a change in epistemic attitude toward a proposition over time: it was unexpected that the V-proposition would be true at the end of the event sequence and it was then found that that proposition was true. Hence, the periphrasis may display concord with other modal and contrastive expressions occurring in the same discourse.

Before moving on to the next section, we consider some data that prima facie go against the idea that [end by V] conveys that the V-proposition was not expected to occur. In these data the periphrasis co-occurs with an expression meaning 'as predicted.' Discourse (33), from Italian, is a case in point:

(33) Un nuovo scettro, forse un po' a sorpresa. Dopo solo una settimana è infatti già finito il 'regno' di Monsters University al botteghino italiano, grazie all'ottima performance fatta segnare da Elysium. [...] Il cartoon Pixar è così stato sconfitto, con un totale arrivato ad oggi ai 6 milioni di euro. Era lecito attendersi qualcosa di più, se non fosse che la concorrenza animata di Turbo, arrivato ai 3 milioni, si sia fatta sentire.

16 We thank an anonymous reviewer for bringing this type of examples to our attention. 
Amaral \& Del Prete

La doppietta animata, come previsto, ha finito the couple animated as predicted have.3SG.PRS.IND end.PTCP per 'dividere' gli incassi del genere, andando automaticamente by share.INF the revenues of.the genre go.GER automatically a deludere entrambi i titoli. to delude.INF both the titles

'Another scepter, maybe a bit unexpected. After only one week the 'reign' of Monsters University at the Italian box office has indeed already ended, thanks to the great performance delivered by Elysium. [...] The Pixar animated movie [Monsters University] has thus been defeated, with a total income of 6 million euros to date. One would reasonably have expected something more, if it were not for the fact that the competition from Turbo, which reached 3 millions, was effective. The animated couple, as predicted, has ended up sharing the revenues of the genre, finally letting both titles down.'

This discourse shows multiple epistemic perspectives with respect to the events of the animated movies achieving revenues. The phrase come previsto 'as predicted' highlights one such perspective: the Turbo movie proved to be as strong as Monsters University and so would likely attract as much public as the latter. Finire per highlights a different perspective: there is a sequence of events that unfolded from the initially unchallenged supremacy of Monsters University, and according to this perspective this movie would dominate the scene and would yield a maximum income. Comparing the relevant sentence in (33) with its variant (34) shows that the latter fails to render the two epistemic perspectives: only the perspective that predicts the two movies to be equally successful is represented in (34).

(34) La doppietta animata, come previsto, ha diviso gli incassi del genere. 'The animated couple, as predicted, has shared the revenues of the genre.'

Therefore, upon inspection of the whole text in which the periphrasis occurs, this example supports our claim that [end by V] contributes an expectationrelated type of modality. What licenses the use of the periphrasis is that in the context there is a perspective for which the eventuality described by $\mathrm{V}$ was seen as less likely than another possible outcome of the event sequence 
Predicting the end: Epistemic change in Romance

(namely, that Monsters University would have supremacy of revenue among animated movies).

Yalcin (2016) also talks of expectations in connection with what he calls "pseudo-epistemic" modals (also called "modals of normality"), exemplified by (35) uttered in the context below (from Yalcin 2016: p. 231):

(35) Context: Jones is in a crowded office building when a severe earthquake hits. The building topples. By sheer accident, nothing falls upon Jones; the building just happens to crumble in such a way so as not to touch the place where he is standing. He emerges from the rubble as the only survivor. Talking to the media, Jones says in wonderment one or other of the following:

I ought to/should be dead now.

Yalcin calls this pseudo-epistemic since he thinks this should be distinguished from genuine epistemic modals like in (36):

(36) The beer must be cold by now.

The main reason for not considering ought to/should epistemic modals is that (35) cannot be paraphrased with any of the uncontroversially epistemic modals. If we replace ought to/should in (35) with one such modal, the resulting sentence has a completely different meaning as shown by (37):

(37) I must be/am probably/might be dead right now.

We think the modality expressed by ought to/should in (32) is epistemic while the fact that must/probably/might cannot replace these modals in (35) only shows that ought to/should require temporal displacement, in other words the modal base must be anchored to a time in the past. This is shown by (38):

(38) [At some relevant time in the past] it was probable that I would be dead now/it might have been the case that I was dead now.

Apart from the issue of whether a distinction between pseudo-epistemic and epistemic modals is empirically justified, one difference between [end by V] and Yalcin's modals of normality is that the former only has a modal projective content without being a modal verb semantically. In addition, what is specific about [end by V] is that expectations are anchored to a presupposed event sequence. The sequence is presupposed in the sense that it is 
salient in the discourse, and it cannot just be in the common ground in the same way as e.g., the existence and uniqueness presuppositions of definite descriptions like "the King of France".

\section{Previous descriptions and analyses}

Several scholars have recognized the puzzling nature of the [end by V] periphrasis. The few mentions of acabar por $V /$ finire per $V$ agree on considering them distinct from the aspectual periphrases - with one exception that we mention last. In this section we review previous accounts of [end by V] both in Italian and Portuguese, and highlight the points that suggest the need for a modal analysis.

For Italian, Bertinetto (1989-1990, 1991) briefly considers finire per $V$ and keeps it separate from aspectual periphrases expressing terminative aspect. Specifically, he describes finire per $V$ (and the semantically similar periphrases finire con il $V_{\mathrm{INF}}$ and finire $V_{\mathrm{GERUND}}$ ) as a "perifrasi risolutiva" in the following passage (our translation of Bertinetto 1991: p. 160; we add glosses and translations to Bertinetto's original examples and change the numbering.):

Risolutive periphrases such as finire per, venir fatto di (the latter being old-stylish), as well as the others mentioned below, have the role of indicating the final achievement of a result. This can be reached through an intentional effort or (more frequently) represent an unexpected outcome:

a. Dopo molti sforzi, gli venne

after several efforts 3SG.CL.DAT come.3SG.PST.IND

fatto di centrare il bersaglio. [(139)]

make.PTCP of hit.INF the target

'After several efforts, he finally could hit the target.'

b. Senza quasi farci caso,

without almost make.INF+LOC.CL case

finì per dirgli tutto.

end.3SG.PST.IND by say.INF+3SG.CL.DAT all

'Without paying attention to it, she ended up telling him everything.'

With respect to Portuguese, while there are several descriptions of the aspectual periphrases formed with acabar and terminar, there are only a few 
Predicting the end: Epistemic change in Romance

mentions of the value of acabar + Gerund or acabar por + Infinitive. Santos (2014) analyzes the periphrases formed with the verb acabar in Brazilian Portuguese and considers the auxiliary verb in acabar + Gerund/acabar por + Infinitive a "modal auxiliary", with a semantic value that is distinct from the one found in the aspectual periphrasis acabar de + Infinitive. However, the author does not provide an analysis of the modal meaning. Travaglia (2002: p. 111) distinguishes this periphrasis from the aspectual one and treats acabar + Gerund/acabar por + Infinitive as a "auxiliar semântico de resultatividade” ('a semantic auxiliary of resultativity').

Medeiros (2018) provides an account of the periphrasis acabar + Gerund in Brazilian Portuguese. Although mostly interested in the syntax of this expression, which is analyzed as an instance of raising, the author provides some insights on the meaning of the periphrasis. The author analyzes acabar as an aspectual verb that converts eventualities in achievements: it takes an eventuality and outputs its minimal final event. He describes the meaning of the periphrasis in the following way (Medeiros 2018: p. 8):

Ao final de um conjunto de situações, e possivelmente a despeito de algumas delas, o evento descrito pelo verbo no gerúndio, que não está incluído nesse conjunto, ocorre.

(Our emphasis. 'At the end of a set of situations, and possibly despite some of them, the event described by the verb in the gerund, which is not included in that set, takes place'.)

This explanation is not explicitly incorporated in the analysis provided. However, in the sentence above the author acknowledges that the interpretation of the periphrasis involves a deviation of some expectation about events. Similarly to our analysis, although not made formally explicit, his description of the contextual conditions licensing the periphrasis agrees with ours, since the scenarios in which the periphrasis is felicitous are those in which the context provides information about the V-event being unlikely. Also in similar spirit to our account, the presupposed event sequence is in Medeiros' account an empty category that has as discourse antecedent a supereventuality, i.e., "um conjunto de eventos concebidos como uma cadeia que temporalmente se encerra no evento da oração não finita” (Medeiros 2018: p. 17, 'a set of events conceived as a chain that temporally ends with the event of the non-finite clause', our translation).

In their seminal studies of verbal periphrases in Romance, Dietrich (1973) and Coseriu (1976) treat the [end by V] periphrasis within the domain of 
aspect. Dietrich introduces an aspectual category that he calls "Situierung" and assigns the Portuguese periphrasis acabar por + INF and Italian finire per + INF to one of its subcategories: "resultierende Handlung" ('resulting action'). For this reason, the periphrases are categorized as aspectual verbal periphrases ("Aspektuelle Verbalperiphrasen"). Another subcategory of the "Situierung" category, called "Einreihung" ('ordering in a series'), is said to include interrelated constructions such as French Je commence par chanter ('I begin by singing') / Je finis par chanter ('I end by singing'), which formally are close to our [end by V] periphrasis.

The mention of the Dietrich-Coseriu aspectual theory allows us to stress that there is a risk of confusion here between formally similar periphrases that express similar but subtly distinct meanings. To illustrate this point, we turn to Bertinetto's 1991 view on Italian verbal periphrases. As we saw above, on the one hand Bertinetto recognizes a "perifrasi risolutiva" finire per + INF, and he says - correctly in our view - that it is to be told apart from the aspectual terminative periphrasis, realized in Italian as finire di + INF / terminare di + INF (he shows that the latter is subject to actional restrictions on the type of verb in INF and is compatible with progressive aspect, unlike the former). On the other hand, he introduces the theoretically close category of the "perifrasi egressiva" ('egressive periphrasis'), characterized as having the "function of indicating the location of a given event with respect to a sequence of other similar events. For instance [finire] col ['finish with the + INF'] indicates [the last] action of a presumed sequence of actions" (Bertinetto 1991: p. 159, our translation). In spite of their conceptual proximity, he considers the "perifrasi egressiva" as distinct from the "perifrasi risolutiva", ${ }^{17}$ although the two categories have overlapping extensions and, what is more, periphrases falling under one category in general are formally similar to periphrases falling under the other. For instance, the periphrases finire con il + INF and finire + GER are considered instances of the egressive periphrasis, but the former is said to also have a reading as a "perifrasi risolutiva." 18

17 Recall that Bertinetto characterizes the "perifrasi risolutiva" as having the function of indicating the final achievement of a given result, which can be the outcome of an intentional effort or (more frequently) represent an unpredicted outcome.

18 The distinction between egressiva and risolutiva is based on two kinds of data (Pier Marco Bertinetto, p.c.):

1. sentences in which finire takes a direct object denoting an event or a sequence of events (as in finire la cena col sorseggiare una grappa 'finish the dinner by sipping a grappa'); in such sentences finire works as an aspectual verb selecting a part of the event denoted by its direct object; 
Predicting the end: Epistemic change in Romance

Beyond these studies, there are no attempts to formally account for the semantic properties of [end by V] in EP or Italian, to which we turn in the next section.

\section{Beliefs and expectations}

Before we provide a formal account of the semantics of [end by V], we need to make a distinction between two kinds of epistemic attitudes, as they are relevant for the interpretations we obtain and they bear on the difference between the periphrasis and the modal particles afinal/alla fine. Hence, the distinction can be linguistically encoded in expressions contributing meanings in the realm of epistemic modality.

\subsection{Two kinds of epistemic attitudes}

A distinction should be drawn between two kinds of epistemic attitudes: (i) a belief regarding whether a certain state holds at present, and (ii) an expectation regarding whether a sequence of events will have a certain outcome. The same attitude verb can be used to express the two kinds of attitude. The verb credere 'believe' can be used in Italian both in sentences like (40a), in which the attitude is directed to a non-dynamic state of affairs, and in sentences like (4ob), in which the attitude is directed to a dynamic event. The same is true of English believe, as shown by the translations of (4Oa)-(4ob):
(40)
a. Credo
che Micha sia
ucraino.
believe.1SG.PRS.IND that Micha be.3SG.PRS.SBJV Ukrainian 'I believe that Micha is Ukrainian.'
b. Credo che Gianni verrà alla festa
believe.1SG.PRS.IND that Gianni come.3SG.FUT.IND at.the party
domani.
tomorrow
'I believe that Gianni will come to the party tomorrow.'

2. sentences in which finire does not take a direct object (i.e., one would obtain a nongrammatical sentence if one tried to add an object NP), as in il bicchiere ha finito col rompersi 'the glass ended up breaking'; in such sentences finire presumably has a different functioning with respect to the aspectual verb. 
On the one hand, from my believing that Micha is Ukrainian, certain expectations may follow, e.g., that if I tried to verify this in the future, I would find that Micha is Ukrainian. However, my belief that Micha is Ukrainian, per se, should not be confused with any such expectation. On the other hand, believing that Gianni will come to the party tomorrow is by itself an expectation: the expectation that some sequence of events running from the present to the future will yield an event of Gianni coming to the party.

This distinction can be illuminated by replacing the 'believe' verb in (40a)(4ob) with an epistemic verb oriented to the future, like desiderare 'wish' (the same pattern is found with European Portuguese desejar):
a. ??Desidero
che Micha sia
ucraino.
wish.1SG.PRS.IND that Micha be.3SG.PRS.SBJV Ukrainian
'I wish that Micha be Ukrainian.'
b. Desidero che Gianni venga alla festa
wish.1SG.PRS.IND that Gianni come.3SG.PRS.SBJV at.the party
domani.
tomorrow

'I wish that Gianni come to the party tomorrow.'

In (41a) the future-oriented verb combines with a stative clause that is understood as temporally linked to the present - whether Micha is Ukrainian is settled by a state obtaining at present. The sentence is odd out of the blue. Our intuition is that it could only be accepted under a coercion to a change of state interpretation for the complement clause, leading to a reading in which some agent can bring about the state of Micha being Ukrainian; crucially, a reading in which the desiderative attitude is directed to a present state (similarly to what is observed in the doxastic ascription I believe that Micha is Ukrainian) is ruled out. The resulting reading of (41a) could thus be paraphrased as in (42):

(42) Desidero che sia fatto qualcosa perché wish.1SG.PRS.IND that be.3SG.PRS.SBJV do.PTCP something so-that Micha diventi ucraino.

Micha become.3SG.PRS.IND Ukrainian

'I wish that something be done so that Micha becomes Ukrainian.' (I)

In (41b), on the other hand, the 'wish' verb combines with an eventive clause temporally linked to a future time and the resulting interpretation has the attitude directed to the future event of Gianni coming to the party. Therefore, 
Predicting the end: Epistemic change in Romance

in both (41a) and (41b) the 'wish' verb displays an orientation to the future: even when the clausal complement denotes a non-dynamic state of affairs, the future orientation lexically encoded by the attitude verb forces an eventive interpretation of its complement. This contrasts with the behavior of the 'believe' verb in (40a)-(4ob), which, so to speak, is lexically neutral with respect to temporal orientation, receiving a present orientation by its stative clause complement in (40a) and a future orientation by its future tense eventive clause complement in (4ob).

Another test for this difference is the co-occurrence with the epistemic verb 'it has been discovered/it has been revealed', as shown by the Portuguese sentences (43a)-(43b):
a. Descobriu
-se que o Micha é
russo.
discover.3SG.PST.IND CL that the Micha be.3SG.PRS.IND Russian
'It was discovered/it came to the fore that Micha is Russian.' (EP)
b. Descobriu -se que o Gianni virá
discover.3SG.PST.IND CL that the Gianni come.3SG.FUT.IND
à festa.
to.the party
'It was discovered that Gianni will come to the party.'

The pattern of interpretation of (43a)-(43b) shows again the difference between beliefs and expectations. While in both cases a certain state of affairs has been revealed, there is a difference between these two examples: in (43a) the discovery is about a present state, while in $(43 \mathrm{~b})$ the discovery is about an event that will take place in the future, Gianni coming to the party. The future event of Gianni coming to the party, unlike the present state of Micha being Russian, is still uncertain: our interpretation of (43b) is that the discovery is about a present state of evidence that determines the expectation of the future event.

Veltman and colleagues have recently used the distinction between beliefs and expectations (Crespo, Karawani \& Veltman 2018). Van Benthem has also proposed this distinction in his logic of games, where beliefs are said to be about where we are right now in a game of imperfect information, in which agents may lack relevant information about past moves or the current state of the game. On the other hand, expectations are about the future course of events in games of perfect information. In the latter type of games, agents have all the relevant information about the game and uncertainty comes in due to the multiplicity of the possible future courses of events - these are 
ordered by relative plausibility through the expectations of an agent (van Benthem 2014). According to van Benthem (p.c.), the distinction between beliefs and expectations may not have made it yet into epistemic logic. Our goal here is to show its importance for natural language semantics.

In the next section we demonstrate that the distinction between an epistemic attitude that is directed to non-dynamic states of affairs in the past or the present - i.e., belief - and an epistemic attitude that is directed to dynamic events unfolding in time - i.e., expectation - allows us to understand the difference between [end by V] and the particles afinal/alla fine. ${ }^{19}$

\subsection{Comparison between the epistemic particles and [end by V]}

Previous research on the particles afinal and alla fine has shown that they are epistemic propositional operators. Specifically, they may combine with (i) plan-related propositions, and with (ii) propositions without plans. In the former case, the speaker had shared a plan with the hearer (where the plan is $p^{*}$ ), and later communicates to the hearer that that plan is not valid anymore, as in (44) and (45):

(44) Afinal ontem fui ao cinema. afinal yesterday go.1SG.PST.IND to.the movies

'Afinal I went to the movies yesterday.'

(45) Alla fine Gianni non è venuto alla festa. alla fine Gianni not be.3SG.PRS.IND come.PTCP to.the party 'Alla fine Gianni did not come to the party.'

For example, (44) would be acceptable in a context in which the speaker had planned on going to some place other than the movie theater (or doing something different from going to the movies), ${ }^{20}$ and had shared that information with the hearer. Note that the proposition that the speaker goes to the movies on the day in question and the previously entertained $p^{*}$ (e.g., the proposition that the speaker does something different from going to the movies on the day in question) are not logically incompatible but they are factually

19 Tawilapakul (2013) compares the meanings of two particles in Thai and distinguishes them on the basis of "denial of expectation" vs "denial of belief" (Tawilapakul 2013: pp. 102-104). Interestingly, the author also proposes a two-propositional structure for the meaning of the particle that contributes counter-expectation: a proposition that expresses a previously entertained expectation and an assertion about the state of affairs at the time of utterance. 20 The identity of the relevant plan may be constrained by focus placement inside the prejacent. 
Predicting the end: Epistemic change in Romance

exclusive: the factual realization of one proposition excludes the factual realization of the other; the same individual cannot be in two different places at the same time. In the case of propositions without plans, speaker and hearer had first shared the belief that a certain proposition $p^{*}$ was true, and then they changed their epistemic attitude toward $p^{*}$ as they have come to believe that $p^{*}$ is false and $p$ (the prejacent) is true. Importantly, in this case there is no event involved and hence no expectation about some event taking place; the sentence that expresses $p$ contains a stative verb, as in (46) and (47):

(46) Afinal o Micha é ucraniano.

afinal the Micha be.3SG.PRS.IND Ukrainian

'Afinal Micha is Ukrainian.'

(47) Alla fine Gianni non era a Roma, mi

alla fine Gianni not be.3SG.IMP.IND at Rome 1SG.CL.REFL

sono sbagliato.

be.1SG.PRS.IND mistake.PTCP

'Alla fine Gianni was not in Rome, I was wrong.'

Sentence (46) can be felicitously uttered if the speaker previously believed that Micha was Russian, and has shared this belief with the hearer. At a later time point, the speaker learns that Micha is Ukrainian (for example, because she saw his passport) and conveys this belief change to the hearer.

Examples (44)-(45) and (46)-(47) show that the particles, like the verb credere 'believe', which is neutral with respect to temporal orientation (section 4.1), are compatible with both stative and eventive prejacents. These examples encode epistemic change: in the case of plan-related propositions, the change affects the plan as well as the speaker's belief about it, while in the case of propositions that are not plan-related, the change pertains to the truth value of the proposition $p^{*}$ as evaluated by an agent at successive times.

When we compare the interpretation of [end by V] with the interpretation of the particles afinal and alla fine, we see that the periphrasis only conveys epistemic change pertaining to an unexpected outcome of an event sequence. On the other hand, the epistemic particles may convey either an unexpected outcome or pure belief change. The periphrasis has a strong preference for non-stative Vs, as shown by the fact that only (48), involving a non-stative $\mathrm{V}$, is an acceptable paraphrase for (45), while (49) is not an acceptable paraphrase for (47): 
(48) Gianni ha finito per non venire alla festa. Gianni have.3SG.PRS.IND end.PTCP by not come.INF to.the party

'Gianni ended up not coming to the party.'

(49) Gianni ha finito per non essere a Roma,

Gianni have.3SG.PRS.IND end.PTCP by not be.INF at Rome

mi sono sbagliato.

1SG.CL.REFL be.1SG.PRS.IND mistake.PTCP

'Gianni ended up not being in Rome, I was wrong.'

The periphrasis is acceptable with a stative $\mathrm{V}$ only when the $\mathrm{V}$ can be coerced to an eventive interpretation. For example, (50) is an acceptable sentence but crucially it has a different meaning from (46):

(50) O Micha acabou por ser ucraniano.

the Micha end.3SG.PST.IND by be.INF Ukrainian

'Micha ended up becoming Ukrainian.' ( $\neq$ meaning of (46))

While (46) means that a change has occurred from a belief that Micha is not Ukrainian to the belief that Micha is Ukrainian, (50) means that an unexpected change has occurred, namely Micha has become Ukrainian. ${ }^{21}$

Corpus data show a strong preference for non-stative Vs with the periphrasis, in both European Portuguese and Italian. For those cases in which the $\mathrm{V}$ is stative we observe two possibilities: (i) either we have an implicit epistemic predicate (like discover, realize, etc.) or (ii) we have coercion to an eventive interpretation, with the meaning of become, as we have just seen in (50). The first possibility involves sentences with a stative V containing a gradable predicate, such as (51) from EP:

(51) As questões técnicas, mesmo se complexas, acabam por the issues technical even if complex end.3PL.PRS.IND by ser as mais simples de tratar. be.INF the most easy to tackle.INF

'The technical issues, even though complex, end up being (recognized as) the ones that are easier to tackle.'

The meaning of (51) is not that the problems had a different degree of complexity at some point in time, and then that degree changed. Rather, the meaning is that at a certain time the subject thought that the problems

21 See the distinction between ontic vs epistemic change drawn by van Ditmarsch \& Kooi (2008). 
Predicting the end: Epistemic change in Romance

were complex, i.e., not easy, and then things evolved and the subject realized that the problems were easy. The interpretation of predicates of taste and gradable predicates involves a judge parameter (Lasersohn 2005, Stephenson 2007); this sentence instantiates a change over time in the evaluation of an underlying judge. Again, we can speak of (51) as expressing an unexpected outcome: one regarding the degree to which the technical issues are evaluated as difficult. In other words, it is as if (51) had an implicit predicate of epistemic experience scoping over the stative verb: the persons that are implicitly understood to have experience of the complex technical issues realize that those questions are simpler than initially expected. Accordingly, in (52) an appropriate paraphrase has to contain a predicate expressing an event of realizing:

(52) Acabámos por descobrir que as questões técnicas, mesmo end.1PL.PST.IND by discover.INF that the issues technical even se complexas, são as mais simples de tratar. if complex be.3PL.PRS.IND the most easy of tackle.INF 'We ended up realizing that the technical issues, though complex, are the ones that are easier to tackle.'

The second possibility, which we saw in (5o), is also exemplified in (53a)-(53b) from Italian:

a. La relazione sui diritti umani finì per essere the report on.the rights human end.3SG.PST.IND by be.INF un documento onesto ed equilibrato. a document honest and balanced 'The human rights report ended up being an honest and balanced document.'

b. Cominciò come una scuola, e finì per begin.3SG.PST.IND as a school and end.3SG.PST.IND by essere un tempio. be.INF a temple 'It began as a schoolhouse and ended up becoming a temple.'

In (53a), after the authors work on the report, they reach an honest and balanced document. In (53b) a certain building is initially intended to be a school and later gets converted into a temple (accordingly, the example can be paraphrased as Cominciò come una scuola, e finì per diventare un tempio 'It began as a schoolhouse and ended up becoming a temple'). 
Another difference between the periphrasis and the epistemic particles pertains to the possibility of temporal binding: while this is possible with the periphrasis, as shown in Section 2.2, it is not possible with the particles. This can be seen by contrasting (54a) (equal to (23) above) and (54b) from EP (the same contrast holds between the corresponding Italian sentences):

a. Sempre que o Pedro tem que tomar uma

Always that the Pedro have.3SG.PRS.IND that take.INF a decisão, acaba por escolher mal.

decision end.3SG.PRS.IND by choose.INF badly

'Every time Pedro has to make a decision, he ends up choosing badly.'

b. Sempre que o Pedro tem que tomar uma

Always that the Pedro have.3SG.PRS.IND that take.INF a decisão, *afinal escolhe mal. decision afinal choose.INF badly 'Every time Pedro has to make a decision, *afinal he chooses badly.'

As shown by this contrast, the presupposed event sequence in (54a) can be bound by the quantificational expression sempre que o Pedro tem que tomar uma decisão but this is not the case for the particle. Moreover, unlike the periphrasis, the particles cannot scope below tense, as shown by the contrast between (55a) and (55b) from EP:

(55) Context: Two brothers decide that they are going to have dinner together.

a. Quando o Pedro chegou para jantar, o irmão

When the Pedro arrive.3SG.PST.IND for dinner, the brother acabou por sair. end.3SG.PST.IND by leave.INF

'When Pedro arrived for dinner, his brother ended up leaving.' (EP)

b. Quando o Pedro chegou para jantar, o irmão When the Pedro arrive.3SG.PST.IND for dinner the brother *afinal saiu.

afinal leave.3SG.PST.IND

'When Pedro arrived for dinner, his brother *afinal left.' 
Predicting the end: Epistemic change in Romance

The comparison in this section reveals that the particles afinal / alla fine are propositional epistemic operators, hence they are anchored to the context of utterance (Hacquard 2006, 2010), while the periphrasis is not.

\section{Formalization of the analysis}

In this section we formalize the semantic analysis given in descriptive terms in Section 2.2 (Section 5.1). Then we compare it with the formal analysis that Amaral \& Del Prete (2016) have proposed for the particles alla fine and afinal (Section 5.2).

\subsection{Semantic analysis of [end by V]}

The denotation function $\llbracket \cdot \rrbracket$ is relativized to a context of utterance $C$ and a world of evaluation $w$. The context $C$ comprises the following parameters:

- the agent $s p_{C}$ who utters the sentence (the speaker of the context);

- the set int ${ }_{C}$ of agents who take part in the exchange (the interlocutors of the context);

- the world of the context $w_{C}$ (the actual world);

- the time of the context $t_{C}$ (the current time);

- the assignment of the context $g_{C}$ (a function assigning $C$-salient values of the right type to free variables).

As standard in a Kaplanian two-dimensional semantics, the denotation of an expression $\alpha$ in a context $C$ is defined as the denotation of $\alpha$ relative to $C$ and the world of $C$, i.e., $\llbracket \alpha \rrbracket_{C, w_{C}}$ (Kaplan 1989: p. 547). Propositions are temporally specific: they are functions from possible worlds to truth values and do not take a time argument - in other words, propositions are about a specific time. ${ }^{22}$

The model structure $M=\left\langle\left\{G_{i}\right\}, T, \preceq_{T}, W, E,\left\{\Omega_{\exp \left\langle G, s^{\rightarrow}, t, w\right\rangle}\right\},\left\{R_{\left\langle G, s^{\rightarrow}, t, w\right\rangle}\right\}\right.$, $\left.\left\{K_{\langle G, t, w\rangle}\right\}\right\rangle$ is presented as follows:

22 We may occasionally say that a proposition holds true at a time. What we mean, in more accurate terms, is that it is a true proposition about the time in question. 
Amaral \& Del Prete

(56) Model structure

a. $\left\{G_{i}\right\}$ is a set of sets $G_{i}$ of epistemic agents;

b. $T$ is a non-empty set, the set of times;

c. $\preceq_{T}$ is a linear order on $T$, the relation of succession between times;

d. $W$ is a non-empty set, the set of possible situations, which includes possible worlds (i.e., maximal situations);

e. $E=\left\langle U_{E}, \rightarrow_{E},><_{E}, S T A R T_{E}, E N D_{E}\right\rangle$ is an event structure where (i) $U_{E}$ is a non-empty set, the set of events (eventualities), including singular and plural events, (ii) ${ }^{E}$ is the "event-sequencing" operation, applying to a set of events $s$ and yielding the plural event $s \rightarrow$, called a sequence of events, (iii) $><_{E}$ is the "abut" two-place relation over $U_{E}$, holding between events $e_{i}$ and $e_{j}$ whenever $e_{i}$ and $e_{j}$ are temporally contiguous, and (iv) $S T A R T_{E}$ and $E N D_{E}$ are oneplace functions on $U_{E}$ mapping events onto their initial and final parts; ${ }^{23}$

f. $\left\{\Omega_{\exp \left\langle G, s^{\rightarrow}, t, w\right\rangle}\right\}$ is a family of sets $\Omega_{\exp \left\langle G, s^{\rightarrow}, t, w\right\rangle} \in \mathscr{P}(\mathscr{P}(W))$ such that $G \in\left\{G_{i}\right\}, s \rightarrow$ is an event sequence, $t \in T, w \in W$ and the propositions $p \in \Omega_{\exp \left\langle G, s^{\rightarrow}, t, w\right\rangle}$ are the propositions that the agents in $G$ jointly accept as possible regarding $\operatorname{END}(s \vec{s})$ at $t$ in $w$ - we call $\Omega_{\exp \left\langle G, s^{\rightarrow}, t, w\right\rangle}$ the expectation state of the set of agents $G$ at time $t$ in world $w$ relative to event sequence $s \rightarrow$

g. $\left\{R_{\left\langle G, s^{\rightarrow}, t, w\right\rangle}\right\}$ is a family of partial relations $R_{\left\langle G, s^{\rightarrow}, t, w\right\rangle}$ over possible worlds, such that $G \in\left\{G_{i}\right\}, s \rightarrow$ is an event sequence, $t \in T, w \in W$ and the field of $R_{\left\langle G, s^{\rightarrow}, t, w\right\rangle}$ is $\cup \Omega_{\exp \left\langle G, s^{\rightarrow}, t, w\right\rangle} ; R_{\left\langle G, s^{\rightarrow}, t, w\right\rangle}$ is a partial order over $\cup \Omega_{\exp \langle G, s \rightarrow, t, w\rangle}$ such that $R_{\langle G, s \rightarrow, t, w\rangle}\left(w_{2}, w_{3}\right)$ if and only if $w_{2}$ is more likely than $w_{3}$ for $G$ at $t$ in $w$ as the outcome state at $\operatorname{END}\left(s^{\rightarrow}\right) ; 24$

23 We omit the subscript " $E$ " for simplicity when no confusion results.

24 We refer to $\Omega_{\exp \left\langle G, s^{\rightarrow}, t, w\right\rangle}$ as a modal base. The reader may wonder why the ranking function (an ordering source) ranges over the generalized union of $\Omega_{\exp \left\langle G, s^{\rightarrow}, t, w\right\rangle}$, given that in Kratzer's modal semantics the ordering source is defined over the intersection of the modal base. The reason we are using generalized union instead is as follows: $\Omega_{\exp \left\langle G, s^{\rightarrow}, t, w\right\rangle}$ is a set of propositions that are candidates for being true of the end of the event sequence, and it may be the case that some of these propositions are incompatible with one another. Hence, the generalized intersection of $\Omega_{\exp \left\langle G, s^{\rightarrow}, t, w\right\rangle}$ may be empty. Choosing generalized union guarantees that the field of the ranking relation $R_{\left\langle G, s^{\rightarrow}, t, w\right\rangle}$ is not empty. 
Predicting the end: Epistemic change in Romance

h. $\left\{K_{\langle G, t, w\rangle}\right\}$ is a family of sets $K_{\langle G, t, w\rangle} \in \mathscr{D}(\mathscr{P}(W))$ such that $G \in$ $\left\{G_{i}\right\}, t \in T, w \in W$ and the propositions $p \in K_{\langle G, t, w\rangle}$ are the propositions known by the agents in $G$ at time $t$ in world $w$, i.e., $K_{\langle G, t, w\rangle}(p)$ means that the agent(s) in $G \operatorname{know}(\mathrm{s})$ the proposition $p$ at $t$ in $w$.

The expectation function $\Omega_{\exp }$ plays a crucial role in our analysis. For a set of agents $G$, sequence of events $s$, time $t$ and world $w, \Omega_{\text {exp }}$ yields the expectation state of $G$ at $t$ in $w$ relative to $s \rightarrow$ : the propositions in the set $\Omega_{\exp \langle G, s \rightarrow, t, w\rangle}$ are those propositions that the agents in $G$ jointly regard as candidates for being true of $\operatorname{END}\left(s^{\rightarrow}\right)$ at $t$ in $w$. In other words, $\Omega_{\text {exp }}$ represents what certain agents expect to become true as the outcome of a sequence of events. We think of $\Omega_{\text {exp }}$ as a further parameter of $C$.

To model (in)felicity of an utterance of sentence $S$ in context $C$ we make use of the concept of (un)definedness of the denotation of $S$ relative to $C$ and the world of $C$. This means that we need a partial function as semantic value of $S$ : a function that will yield a determinate value (i.e., will be defined) for some arguments but no determinate value (i.e., will not be defined) for others.

(57) Partial functions (see Heim \& Kratzer 1998: p. 34)

$\lambda x: \phi[x] . \psi[x]$ is the function $f$ such that:

a. $f$ is defined for an object $x$ if and only if the definedness condition $\phi$ is satisfied;

b. if defined for $x, f$ assigns to $x$ whatever value is described by $\psi$.

The application of the function $\lambda x: \phi[x] . \psi[x]$ to object $a$ yields $\{\phi[a]\} \psi[a]$. The formula $\{\phi[a]\} \psi[a]$ is equivalent to the formula $\psi[a]$, provided that the definedness condition $\phi[a]$ is satisfied. If the definedness condition $\phi[a]$ is not satisfied, $\{\phi[a]\} \psi[a]$ is undefined.

We can now provide the semantic clause for the [end by V] periphrasis as follows:

(58) $\llbracket$ acabar-por/finire-per $\rrbracket_{C, w}=\lambda P_{\langle\mathrm{s},\langle\mathrm{E}, \mathrm{t}\rangle\rangle}$ :

a. $\exists ! s^{\rightarrow} \exists p^{*} \exists G^{*}\left[K_{\left\langle\text {int }_{C}, t_{C}, w\right\rangle}\left(p^{*} \in \Omega_{\exp \left\langle G^{*}, s^{\rightarrow}, S T A R T\left(s^{\rightarrow}\right), w\right\rangle}\right)\right.$

$\wedge \exists w_{0}\left[w_{0} \in p^{*} \wedge \forall w_{1}\left[w_{1} \in\left(\lambda w . \exists e\left[e><\operatorname{END}\left(s^{\rightarrow}\right) \wedge P(w, e)\right]\right)\right.\right.$

$\left.\left.\left.\rightarrow R_{\left\langle G^{*}, s^{\rightarrow}, S T A R T\left(s^{\rightarrow}\right), w\right\rangle}\left(w_{0}, w_{1}\right)\right]\right]\right]$.

(Presupposition) 
b. $\exists ! s^{\rightarrow} \exists p^{*} \exists G^{*}\left[K_{\left\langle i n t_{c}, t_{c}, w\right\rangle}\left(p^{*} \in \Omega_{\exp \left\langle G^{*}, s^{\rightarrow}, S T A R T\left(s^{\rightarrow}\right), w\right\rangle}\right)\right.$

$\wedge \exists w_{0}\left[w_{0} \in p^{*} \wedge \forall w_{1}\left[w_{1} \in\left(\lambda w . \exists e\left[e><\operatorname{END}\left(s^{\rightarrow}\right) \wedge P(w, e)\right]\right)\right.\right.$

$\left.\left.\left.\rightarrow R_{\left\langle G^{*}, s^{\rightarrow}, \operatorname{START}\left(s^{\rightarrow}\right), w\right\rangle}\left(w_{0}, w_{1}\right)\right]\right] \wedge \exists e\left[e><\operatorname{END}\left(s^{\rightarrow}\right) \wedge P(w, e)\right]\right]$

$(\text { Assertion })^{25}$

Note that $\Omega_{\text {exp }\left\langle G^{*}, s^{\rightarrow}, S T A R T\left(s^{\rightarrow}\right), w\right\rangle}$ is a set of propositions about a particular point in time, namely $E N D\left(s^{\rightarrow}\right)$, representing an attitude of expectation held at another particular point in time, namely $\operatorname{START}(s \rightarrow)$. In addition, we should point out that the existential quantifier over eventualities $\exists e$ in (58) is not restricted to a domain of non-stative eventualities. The "abut" condition $e><$ $\operatorname{END}(s)$ only requires that $e$ be an eventuality that allows for temporal location, and it is known that some stative eventualities do allow for that (e.g., John turned the light off and it was pitch dark). The analysis in (58) thus predicts that [end by V] admits stative Vs insofar as these denote stative eventualities allowing for temporal location (see the contrasts in (15c)-(15d) and (24a)-(24b) above).

Importantly, we could not account for the meaning of the periphrasis using the analysis typically proposed for modal verbs such as must and might: the semantics in (58) makes use of a sequence of events $s \rightarrow$ and requires anchoring of the modal base to the initial point of $s$; this temporal anchor is displaced from the point representing the evaluation time and is in the past of it (i.e., the modal component of the meaning of [end by V] is past). Note that, for past tensed [end by V]-sentences, two time points in the past have to be entertained: a point $t_{1}$, coinciding with the endpoint of the event sequence, which provides the time at which the V-eventuality occurs, and a point $t_{2}$ in the past of $t_{1}$ and coinciding with the initial point of the event sequence, to which the modal base is anchored.

\subsection{Application of the analysis}

We show how the analysis applies to some of the previously considered examples. We start with the case in which only one expectation is involved, and then we move to a more complex case, involving two contrasting expectations. Consider (1a), repeated below as (59):

25 In the semantic clause in (58) we assume that $S T A R T(s)$ is mapped onto its temporal trace. Strictly speaking, the functions $S T A R T_{E}$ and $E N D_{E}$ output a part of an event, not a time. 
Predicting the end: Epistemic change in Romance

(59) Depois de uma manhã de sol acabou por chover.

'After a sunny morning it ended up raining.'

Ignoring for simplicity the initial temporal adverbial, the LF of this sentence is (6o) and its truth-conditional evaluation in context is given in (61) (we do not have a compositional account of the interaction between tense and [end by V]; we assume that a temporally indexed tense $\mathrm{PAST}_{k}$ requires that the $\mathrm{V}$-event in the assertion be temporally included in the interval $g_{C}(k)$ that the context assignment $g_{C}$ assigns to the variable $k$ carried by the tense, where $g_{C}(k)$ must be in the past of the context time):

(6o) [PAST $k$ [acabar-por[chover]]]

(61) $\llbracket\left[\mathrm{PAST}_{k}\right.$ [acabar-por[chover $\left.\left.]\right]\right] \rrbracket_{C, w_{C}}=1$ iff

$$
\llbracket \mathrm{PAST}_{k} \rrbracket_{C, w_{C}}\left(\llbracket \text { acabar-por } \rrbracket_{C, w_{C}}(\lambda w \cdot \lambda e \cdot R A I N(w, e))\right)=1 \text { iff }
$$
$\left\{\exists ! s^{\rightarrow} \exists p^{*} \exists G^{*}\left[K_{\left\langle\text {int }_{C}, t_{C}, w_{C}\right\rangle}\left(p^{*} \in \Omega_{\exp \left\langle G^{*}, s^{\rightarrow}, S T A R T\left(s^{\rightarrow}\right), w_{C}\right\rangle}\right) \wedge \exists w_{0}\left[w_{0} \in p^{*}\right.\right.\right.$ $\wedge \forall w_{1}\left[w_{1} \in\left(\lambda w . \exists e\left[e><\operatorname{END}\left(s^{\rightarrow}\right) \wedge \operatorname{RAIN}(w, e)\right]\right)\right.$

$$
\begin{array}{r}
\left.\left.\left.\left.\rightarrow R_{\left\langle G^{*}, s^{\rightarrow}, S T A R T\left(s^{\rightarrow}\right), w_{C}\right\rangle}\left(w_{0}, w_{1}\right)\right]\right]\right]\right\} \\
\exists ! s^{\rightarrow} \exists p^{*} \exists G^{*}\left[K _ { \langle i n t _ { C } , t _ { C } , w _ { C } \rangle } \left(p ^ { * } \in \Omega _ { e x p \langle G ^ { * } , s ^ { \rightarrow } , S T A R T ( s \rightarrow ) , w _ { C } \rangle } \wedge \exists w _ { 0 } \left[w_{0} \in p^{*}\right.\right.\right. \\
\wedge \forall w_{1}\left[w_{1} \in\left(\lambda w . \exists e\left[e><\operatorname{END}\left(s^{\rightarrow}\right) \wedge R A I N(w, e)\right]\right)\right. \\
\left.\left.\rightarrow R_{\left\langle G^{*}, s^{\rightarrow}, \operatorname{START}\left(s^{\rightarrow}\right), w_{C}\right\rangle}\left(w_{0}, w_{1}\right)\right]\right] \wedge \exists e\left[e><E N D\left(s^{\rightarrow}\right)\right. \\
\left.\left.\wedge \tau\left(e, w_{C}\right) \subseteq g_{C}(k) \wedge R A I N\left(w_{C}, e\right)\right]\right]
\end{array}
$$

According to (61), sentence (59) is true in context $C$ if there is an event abutting the end of a presupposed sequence $s \vec{s}$, the event is temporally included in a $C$-salient past interval and it is an event of rain in the world of $C$. Furthermore, the analysis predicts that (59) is defined in $C$ at the condition that the proposition that there is an event of rain abutting the end of the sequence $s \rightarrow$ is ranked lower than some alternative proposition that is known by the interlocutors of $C$ to have been in the expectation state of a set of agents at the beginning of the same sequence.

We now turn to example (33), from Section 2.3, involving two contrasting expectations. We repeat the relevant sentence as (62):

(62) La doppietta animata, come previsto, ha finito per dividere gli incassi del genere.

'The animated couple, as predicted, has ended up sharing the genre's revenues.' 
As we said in Section 2.3, the phrase come previsto 'as predicted' and the [end by V] periphrasis are anchored to different epistemic perspectives. In our account, the meaning of (62) is computed on the basis of a conjunction, as in (63):

(63) [La doppietta animata ha finito per dividere gli incassi del genere] \& [come previsto la doppietta animata ha diviso gli incassi del genere] 'The animated couple has ended up sharing the genre's revenues \& as predicted the animated couple has shared the genre's revenues.'

In (63), the contribution of come previsto and the contribution of the periphrasis are shown to be independent from each other. We assume that come previsto is a propositional modal operator indexed to a group of agents, a sequence of events and a time. In this indexation, the utterance of a sentence ${ }^{\ulcorner}$come-previsto(S) $\urcorner$in a context $C$ is always interpreted as saying that the proposition expressed by $\mathrm{S}$ follows from expectations entertained by a $C$-relevant group of agents at a $C$-relevant time, relative to a $C$-relevant sequence. The modal operator carries a triple of variables $\langle G, \vec{s}, t\rangle$ (for groups of agents, event sequences and times), each receiving a value under the contextual assignment $g_{C}$, and it has the following semantics:

$$
\llbracket \text { come-previsto }\left\langle G_{\left.G_{0}, s_{0}, t_{0}\right\rangle} \rrbracket_{C, w}=\lambda p . p \in \Omega_{\exp \left\langle g_{C}\left(G_{0}\right), g_{C}\left(\vec{s}_{0}\right), g_{C}\left(t_{0}\right), w\right\rangle}\right.
$$

Our analysis of (62) posits the LF (65), ${ }^{26}$ which is evaluated in context as in (66) ('ACSR' stands for the event property 'animated-couple-shares-revenues'):

(65) $\quad\left[\mathrm{PAST}_{k}\right.$ [finire-per[doppietta animata divide incassi]]]

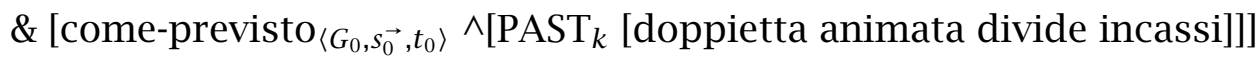

$$
\begin{aligned}
& \llbracket(65) \rrbracket_{C, w_{C}}=1 \text { iff } \\
& \left\{\exists ! s _ { 1 } \exists p ^ { * } \exists G ^ { * } \left[K _ { \langle i n t c , t _ { c } , w _ { C } \rangle } ( p ^ { * } \in \Omega _ { \operatorname { e x p } \langle G ^ { * } , s _ { 1 } , S T A R T ( s _ { 1 } ) , w _ { C } \rangle } ) \wedge \exists w _ { 0 } \left[w_{0} \in p^{*}\right.\right.\right. \\
& \wedge \forall w_{1}\left[w_{1} \in\left(\lambda w . \exists e\left[e><\operatorname{END}\left(s_{1}\right) \wedge \operatorname{ACSR}(w, e)\right]\right)\right. \\
& \left.\left.\left.\left.\rightarrow R_{\left\langle G^{*}, \vec{s}_{1}, \operatorname{START}\left(\vec{s}_{1}\right), w_{C}\right\rangle}\left(w_{0}, w_{1}\right)\right]\right]\right]\right\} \\
& \exists ! s_{1} \exists p^{*} \exists G^{*}\left[K _ { \langle i n t _ { C } , t _ { C } , w _ { C } \rangle } ( p ^ { * } \in \Omega _ { \operatorname { e x p } \langle G ^ { * } , s _ { 1 } , S T A R T ( s _ { 1 } ) , w _ { C } \rangle } ) \wedge \exists w _ { 0 } \left[w_{0} \in p^{*}\right.\right. \\
& \wedge \forall w_{1}\left[w_{1} \in\left(\lambda w \cdot \exists e\left[e><\operatorname{END}\left(s_{1}\right) \wedge \operatorname{ACSR}(w, e)\right]\right)\right. \\
& \left.\left.\rightarrow R_{\left\langle G^{*}, s_{1}, \operatorname{START}\left(\overrightarrow{s_{1}}\right), w_{C}\right\rangle}\left(w_{0}, w_{1}\right)\right]\right] \wedge \exists e\left[e><\operatorname{END}\left(\overrightarrow{s_{1}}\right)\right.
\end{aligned}
$$

26 The intensionalizing operator $\wedge$ applies to the LF $S^{\prime}$ of a sentence $S$ and yields an expression $\wedge S^{\prime}$ which denotes the proposition expressed by $S^{\prime}$. The operator $\wedge$ is needed in (65) in order to provide an argument of the right kind (that is, a proposition) to the modal operator come previsto. 
Predicting the end: Epistemic change in Romance

$$
\begin{aligned}
\wedge \tau\left(e, w_{C}\right) \subseteq g_{C}(k) \wedge & \left.\left.\operatorname{ACSR}\left(w_{C}, e\right)\right]\right] \wedge\left(\lambda w \cdot \exists e \left[\tau(e, w) \subseteq g_{C}(k)\right.\right. \\
& \wedge \operatorname{ACSR}(w, e)]) \in \Omega_{e x p}\left\langle g_{C}\left(G_{0}\right), g_{C}\left(s_{0}\right), g_{C}\left(t_{0}\right), w_{C}\right\rangle
\end{aligned}
$$

According to (66), sentence (62) is true in context $C$ at the following conditions:

(a) there is an actual event abutting the end of the presupposed sequence

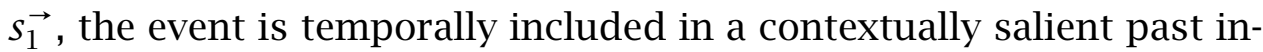
terval $g_{C}(k)$ and it is an event of the two animated movies sharing the genre's revenues,

(b) the proposition that there is an event included in $g_{C}(k)$ of the two animated movies sharing the genre's revenues was expected by some contextually salient set of agents at some contextually salient time.

Furthermore, the analysis predicts that (the [end by V] component of) (62) is defined in $C$ at the following condition:

(c) the proposition that there is an event of the two animated movies sharing the genre's revenues abutting the end of the presupposed sequence $s_{1}$ is ranked lower than some alternative proposition that is known by the interlocutors of $C$ to have been in the expectation state of a set of agents $G^{*}$ at the beginning of $\vec{s}_{1}$.

Crucially, the expectations in (b) and (c) can come from different $\Omega_{\text {exp }}$-sets: the set-of-agents and time parameters of the $\Omega_{\text {exp }}$-function need not have the same values in the case of [end by V] and in the case of come previsto.

\subsection{Comparison between the formal analyses of the periphrasis and the particles}

Amaral \& Del Prete (2016) propose the following semantics for the particles afinal / alla fine:

(67) $\llbracket$ afinal/alla fine $\rrbracket_{C, T^{*}, w}=\lambda p$ :

$$
\begin{aligned}
& \exists p^{*} \exists G^{*} \exists t_{1}\left[t_{1} \preceq_{T} \operatorname{END}\left(T^{*}\right) \wedge K_{\text {int }_{C}}\left(\Omega_{\left\langle G^{*}, t_{1}, w\right\rangle} \subseteq p^{*}\right) \wedge\left(p^{*} \cap p\right)=\varnothing\right] . \\
& p(w)=1 \wedge \forall w_{3}\left[\left[w _ { 3 } \in \Omega _ { \langle s p _ { C } , E N D ( T ^ { * } ) , w \rangle } \wedge \neg \exists w _ { 2 } \left[w_{2} \in \Omega_{\left\langle s p_{C}, E N D\left(T^{*}\right), w\right\rangle}\right.\right.\right. \\
& \left.\left.\left.\wedge R_{\left\langle s p_{C}, E N D\left(T^{*}\right), w\right\rangle}\left(w_{2}, w_{3}\right)\right]\right] \rightarrow p\left(w_{3}\right)=1\right] \\
& \text { (Assertion) }
\end{aligned}
$$


According to (67), relative to a context $C$, time interval $T^{*}$ and world of evaluation $w$, afinal / alla fine denotes a partial function $f$ from propositions to truth values such that:

(a) $f(p)$ is defined only if $p$ is incompatible with a proposition $p^{*}$ which the interlocutors of $C$ know to have been the object of the belief or expectation of the epistemic agents in a group $G^{*}$ at a time $t_{1}$ in the evaluation interval $T^{*}$ that is before the endpoint of $T^{*}$;

(b) whenever defined, $f(p)$ is true if $p$ is true at the world of evaluation $w$ and at all best epistemic worlds accessible for the speaker of $C$ at the endpoint of $T^{*}$ in the world of evaluation $w$.

The set of agents $G^{*}$ may consist of the interlocutors of the context of utterance or other agents whose perspectives on the eventualities referred to in the discourse are relevant. However, the analysis in (67) makes also reference to the interlocutors of the context, as it ascribes to them the shared knowledge that the proposition $p^{*}$ characterizes (i.e., is true in all worlds in) the epistemic state of $G^{*}$ at the past time $t_{1}$. Moreover, it refers to the epistemic state of the speaker $s p_{C}$, by requiring that the prejacent $p$ hold true at all best epistemic worlds accessible for $s p_{C}$ at the endpoint of the evaluation interval $T^{*}$ in the world of evaluation.

The analysis we have proposed for the [end by V] periphrasis and the one proposed for afinal/alla fine differ in the following respects. First, in the analysis of the particles there is no presupposed event sequence. The analysis of the particles posits instead a dependence on a time interval parameter $T^{*}$, which is similar in status to the context parameter $C$. In particular, the $T^{*}$ parameter, unlike the event sequence in the analysis of [end by V], cannot be bound - which explains the difference between the particles and the periphrasis with respect to the possibility of temporal binding (see the contrast in (54a)-(54b) in Section 4.2). Second, Amaral \& Del Prete (2016) make use of a more general epistemic function $\Omega$ that keeps track of both beliefs and expectations of a set of agents, and of how these attitudes evolve over time. For a set of agents $G$, time $t$ and world $w$, this function $\Omega$ selects the epistemic state of $G$ at $t$ in $w$, defined as the set of worlds compatible with all the propositions that the agents in $G$ accept as true at $t$ in $w$-these propositions can be about a time in the past, the present or the future of $t$. In sentences pertaining to beliefs, $\Omega$ records the fact that a (set of) agent(s) $G$ had the (joint) belief at a time $t$ that a certain proposition $p$ was true and $G$ 
Predicting the end: Epistemic change in Romance

retains at the current time $t_{C}$ the belief that $p$ is true (since epistemic states and propositions are both sets of possible worlds, this fact is represented via the relational formulas $\Omega_{\langle G, t, w\rangle} \subseteq p$ and $\Omega_{\left\langle G, t_{c}, w\right\rangle} \subseteq p$ ). This formal device is important in order to account for the interpretation of cases in which $\Omega$ records an epistemic change (e.g., for sentences like (46)-(47)), namely, an agent had the belief at a time $t$ that a certain proposition $p$ was true and the same agent forms the belief at a subsequent time $t^{\prime}$ that $\sim p$ is true, where $\sim p$ is a proposition factually incompatible with $p$, not necessarily the logical negation of $p$. The expectation function $\Omega_{\text {exp }}$ differs from Amaral and Del Prete's epistemic function $\Omega$ in that $\Omega_{\text {exp }}$ only selects propositions about the end of the event sequence: $\Omega_{\exp \left\langle G, s^{\rightarrow}, t, w\right\rangle}$ is the set of only those propositions that the agents in $G$ jointly consider possible regarding $E N D(s)$ at $t$ in $w$. Therefore, if we look at Amaral and Del Prete's $\Omega_{\langle G, t, w\rangle}$ in terms of a set of propositions, we see that $\Omega_{\exp \left\langle G, s^{\rightarrow}, t, w\right\rangle}$ is a set smaller than $\Omega_{\langle G, t, w\rangle}$ : the former contains only some of the propositions in the latter. With this change we can account for the meaning of the periphrasis in a more intuitive way by focusing only on expectations as the relevant modal base ( $p^{*}$ is now one of the members of $\Omega_{\text {exp }}$ ). Finally, while in Amaral and Del Prete's analysis of the epistemic particles it is proposed that both meaning components are modal, in our analysis of the periphrasis only the presupposed component is modal; the assertion is equivalent to the proposition expressed by the inflected $\mathrm{V}$.

\section{Conclusion}

In this paper we demonstrated that the periphrasis [end by V] in EP and I is not aspectual but rather a periphrasis contributing expectation-related modality. We have provided a semantic analysis of [end by V] that accounts for its contextual constraints. We have also shown the similarities and differences between the periphrasis and the epistemic particles afinal/alla fine that convey a meaning of truth unpersistence (based on the analysis of Amaral \& Del Prete 2016). While it was not our goal to provide a full-fledged account of the syntactic and semantic properties of [end by V], we have identified a set of key features of this periphrasis that lay the ground for its examination in future research.

The study of [end by V] expands our knowledge of the encoding of epistemic modality in natural languages. In this respect, our paper contributes to defining the landscape of epistemic modality. While much of the work in this area is based on modal verbs like must and might (Kratzer 2012, von Fintel \& 
Gillies 2007, 2011, Condoravdi 2002), we propose that this Romance verbal periphrasis also conveys a meaning in the domain of epistemic modality and displays a complex interaction with other semantic domains. We argue that the type of modality involved is epistemic, because the contribution of the periphrasis pertains to an attitude that, like belief, agents bear toward propositions. Specifically, the periphrasis conveys a change in this propositional attitude over time.

Our analysis builds on quantification over possible worlds and introduces some new elements in order to account for the meaning of the periphrasis. While Kratzer (1981) has proposed the conversational background as a crucial parameter in the semantics of modals (including epistemic modals), we show that a presupposed event sequence must be taken into account in order to model the meaning of [end by V]. Accordingly, our formal analysis expands a Kratzer-style analysis: we make use of a sequence of events and anchor the modal base to a point which is not the time of evaluation of the sentence, but rather coincides with the starting point of the event sequence (i.e., the modal base is evaluated in the past). The function $\Omega_{\text {exp }}$ captures the fact that the epistemic attitude relevant for the interpretation of the periphrasis is the expectation that some agents held at the beginning of the event sequence, regarding the outcome of the latter. Our analysis also posits a two-propositional structure involving a modal presupposition and a factual assertion, akin to the behavior of Karttunen's two-way implicatives. The meaning of [end by V] is more complex than that of standard modal verbs the periphrasis requires shared knowledge of a previous expectation about the outcome of a certain event sequence, where the outcome described by $\mathrm{V}$ is unexpected. Hence, the modal meaning of [end by V] interacts with temporal orderings and discourse structure.

Since the periphrasis conveys the meaning that an event is unexpected, one may ask which relation, if any, it bears to mirativity, "the linguistic marking of an utterance as conveying information which is new or unexpected to the speaker" (DeLancey 1997: p. 370). In particular, unexpectedness on the part of some agent has been included as one of the semantic values in the range of mirative meanings (Aikhenvald 2012: p. 437). While epistemic modality and, in particular, evidentiality are generally recognized as categories closely related to mirativity, we believe that the periphrasis cannot be said to semantically encode mirativity and could at most be regarded as a "mirative strategy" in Aikhenvald's 2004 sense - its occasional association with surprise or an unprepared mind, which Aikhenvald proposes to be 
Predicting the end: Epistemic change in Romance

characteristic of mirative expressions, rather appears to us to be a pragmatic effect.

Our comparison between [end by V] and the particles afinal/alla fine shows that there are different types of epistemic change and that natural languages may encode such differences. We have proposed a distinction between two types of epistemic attitudes, belief and expectation. The distinction between belief and expectation has also been found to be relevant in modal logic, specifically in the logical analysis of games developed by van Benthem (2014). Van Benthem emphasizes that the common idea of belief really covers two different notions; although they are close in that both involve plausibility comparisons, they nevertheless play distinct logical roles. As we show in this paper, these roles become visible in the behavior of certain linguistic expressions. The epistemic particles afinal/alla fine encode what van Benthem calls "the dynamics of correction" (van Benthem 2014: p. 159), i.e., they express acts of belief change by rational agents. These acts can target either previous beliefs (in the strictest sense) about non-dynamic states of affairs, relative to which the holder of the belief lacked relevant information, or previous expectations about dynamic events unfolding in time. On the other hand, [end by V] specifically targets previous expectations. Research in natural language semantics has shown the relevance of expectations for a range of linguistic expressions (Crespo, Karawani \& Veltman 2018), for instance for the interpretation of certain particles in Thai, by highlighting the way in which expectations interact with the question under discussion (Tawilapakul 2013).

Previous work has highlighted the importance of plans (i.e., courses of events that are controllable or subject to volition and intention), both ontologically and semantically; the modal systems of languages are sensitive to sequences of events that may evolve either in accordance to or counter to what was planned by an agent (Amaral \& Del Prete 2016, 2017, Copley 2008, 2009, 2018). Here we also contribute to this line of research by showing that the constraints displayed by [end by V] attest to the linguistic relevance of expectations, plans being a proper subset of expectations about courses of events.

Our paper lays the ground for further studies on epistemic change, possibly on tendencies in the encoding of the distinction between beliefs and expectations in other natural languages. 
Amaral \& Del Prete

\section{References}

Aikhenvald, Alexandra. 2004. Evidentiality. Oxford: Oxford University Press. Aikhenvald, Alexandra. 2012. The essence of mirativity. Linguistic Typology 16(3). 435-485. https://doi.org/10.1515/lity-2012-0017.

Amaral, Patrícia \& Fabio Del Prete. 2014. On truth persistence: A comparison between European Portuguese and Italian in relation to sempre. In Marie-Helene Côté, Eric Mathieu \& Shana Poplack (eds.), Variation within and across romance languages: Selected papers from the 41st linguistic symposium on Romance languages, 1-14. Amsterdam: John Benjamins. https://doi.org/10.1075/cilt.333.11ama.

Amaral, Patrícia \& Fabio Del Prete. 2016. On truth unpersistence: At the crossroads of epistemic modality and discourse. Natural Language and Linguistic Theory 34(4). 1135-1165. https://doi.org/10.1007/s11049-015-932 5-5.

Amaral, Patrícia \& Fabio Del Prete. 2017. Modality, presupposition and discourse. In Ruth E.V. Lopes, Juanito Ornelas de Avelar \& Sonia M. L. Cyrino (eds.), Romance languages and linguistic theory 12: Selected papers from the 45th linguistic symposium on Romance languages, 1-14. Amsterdam: John Benjamins. https://doi.org/10.1075/rllt.12.01ama.

van der Auwera, Johan \& Andreas Ammann. 2013. Overlap between situational and epistemic modal marking. In Matthew S. Dryer \& Martin Haspelmath (eds.), The world atlas of language structures online. Leipzig: Max Planck Institute for Evolutionary Anthropology. https://wals.info/chapt er $/ 76$.

Bach, Emmon. 1981. On time, tense, and aspects: An essay in English metaphysics. In Peter Cole (ed.), Radical pragmatics, 63-81. New York: Academic Press.

van Benthem, Johan. 2014. Logic in games. Cambridge MA: The MIT Press. https://doi.org/10.7551/mitpress/9674.001.0oo1.

Bertinetto, Pier Marco. 1989-1990. Le perifrasi verbali italiane: Saggio di analisi descrittiva e contrastiva. Quaderni Patavini di linguistica 8/9. 27-64.

Bertinetto, Pier Marco. 1991. Il verbo. In Lorenzo Renzi \& Giampaolo Salvi (eds.), Grande grammatica italiana di consultazione, ii: I sintagmi verbale, aggettivale, avverbiale. la subordinazione, 13-161. Bologna: Il Mulino.

Bertucci, Roberlei. 2011. Eventualidades incrementais e a semântica de terminar. Cadernos de Estudos da Linguagem 53(1). 73-91. https://doi.org/1 o.20396/cel.v53i1.8636545. 
Predicting the end: Epistemic change in Romance

Bertucci, Roberlei. 2015. Aspectual verbs: Their complements and operations. In Emmanuelle Labeau \& Qiaochao Zhang (eds.), Taming the TAME systems, vol. 27 (Cahiers Chronos), 101-122. https://doi.org/10.1163/97890 04292772_007.

Condoravdi, Cleo. 2002. Temporal interpretation of modals: Modals for the present and for the past. In David Beaver, Luis Casillas Martínez, Brady Clark \& Stefan Kaufmann (eds.), The construction of meaning. Stanford: CSLI Publications.

Copley, Bridget. 2008. The plan's the thing: Deconstructing futurate meanings. Linguistic Inquiry 39(2). 261-274. https://doi.org/10.1162/ling.2008 .39 .2 .261 .

Copley, Bridget. 2009. The semantics of the future. New York: Routledge Outstanding Dissertations in Linguistics. https://doi.org/10.4324/97802038 80258.

Copley, Bridget. 2018. Dispositional causation. Glossa: A Journal of General Linguistics 3(1). 137. https://doi.org/10.5334/gjgl.507.

Coseriu, Eugenio. 1976. Das romanische Verbalsystem. Tübingen: Narr.

Crespo, Inés, Hadil Karawani \& Frank Veltman. 2018. Expressing expectations. In Brian Rabern \& David Ball (eds.), The science of meaning: Essays on the metatheory of natural language semantics, 32-62. Oxford: Oxford University Press. https://doi.org/10.1093/oso/9780198739548.003.0oo9. Cunha, Luís Filipe. 1998. As construções com Progressivo no Português: Uma abordagem semântica. Porto: Faculdade de Letras da Universidade do Porto MA thesis.

DeLancey, Scott. 1997. Mirativity: New vs. assimilated knowledge as a semantic and grammatical category. Linguistic Typology 1(1). 33-52. https://doi .org/10.1515/lity.1997.1.1.33.

Dietrich, Wolf. 1973. Der periphrastische Verbalaspekt in den romanischen Sprachen. Vol. 140 (Beihefte zur Zeitschrift für romanische Philologie). Tübingen: Max Niemeyer Verlag. https://doi.org/10.1515/9783111328201. van Ditmarsch, Hans \& Barteld Kooi. 2008. Semantic results for ontic and epistemic change. In Giacomo Bonanno, Wiebe van der Hoek \& Michael Wooldridge (eds.), Logic and the foundations of game and decision theory (LOFT 7), vol. 3 (Texts in Logic and Games), 87-117. Amsterdam: Amsterdam University Press.

von Fintel, Kai \& Anthony S. Gillies. 2007. An opinionated guide to epistemic modality. In Tamar Szabó Gendler \& John Hawthorne (eds.), Oxford studies in epistemology 2, 32-62. Oxford: Oxford University Press. 
Amaral \& Del Prete

von Fintel, Kai \& Anthony S. Gillies. 2011. Might made right. In Andy Egan \& Brian Weatherson (eds.), Epistemic modality. Oxford: Oxford University Press. https://doi.org/10.1093/acprof:oso/9780199591596.003.0004.

Giannakidou, Anastasia \& Alda Mari. 2018a. A unified analysis of the future as epistemic modality: The view from Greek and Italian. Natural Language and Linguistics Theory 36(1). 85-129. https://doi.org/10.1007/s11049-01 7-9366-z.

Giannakidou, Anastasia \& Alda Mari. 2018b. Veridicality in grammar and thought: Modality, propositional attitudes and negation. Chicago: University of Chicago Press.

Hacquard, Valentine. 2006. Aspects of modality. Boston: MIT dissertation.

Hacquard, Valentine. 2010. On the event relativity of modal auxiliaries. Natural Language Semantics 18(1). 79-114. https://doi.org/10.1007/s11050o10-9056-4.

Harris, Zellig. 1954. Distributional structure. Word 10(2-3). 146-162. https://d oi.org/10.1080/00437956.1954.11659520.

Heim, Irene \& Angelika Kratzer. 1998. Semantics in generative grammar. Oxford: Blackwell.

Kaplan, David. 1989. Demonstratives: An essay on the semantics, logic, metaphysics, and epistemology of demonstratives and other indexicals. In Joseph Almog, John Perry \& Howard Wettstein (eds.), Themes from $\mathrm{Ka}$ plan, 481-564. Oxford: Oxford University Press.

Karttunen, Lauri. 1971. Implicative verbs. Language 47(2). 340-358. https://d oi.org/10.2307/412084.

Kratzer, Angelika. 1981. The notional category of modality. In Hans J. Eikmeyer \& Hannes Rieser (eds.), Words, worlds, and contexts, vol. 6 (Research in Text Theory), 38-74. Berlin \& New York: de Gruyter. https://doi.org/1 0.1515/9783110842524-004.

Kratzer, Angelika. 2012. Modals and conditionals: New and revised perspectives. Oxford: Oxford University Press. https://doi.org/10.1093/acprof:o so/9780199234684.001.00o1.

Laca, Brenda. 2002. Romance "aspectual” periphrases: Eventuality modification versus "syntactic" aspect. In Jacqueline Guéron \& Jacqueline Lecarme (eds.), The syntax of time, 425-440. Cambridge MA: The MIT Press.

Laca, Brenda. 2004. Les catégories aspectuelles à expression périphrastique: Une interprétation des apparentes « lacunes » du français. Langue française 141(1). 85-98. https://doi.org/10.3917/lf.141.0085. 
Predicting the end: Epistemic change in Romance

Laca, Brenda. 2005. Périphrases aspectuelles et temps grammaticale dans les langues romanes. In Hava Bat-Zeev Shyldkrot \& Nicole Le Querler (eds.), Les périphrases verbales, 47-66. Amsterdam: John Benjamins. https://d oi.org/10.1075/lis.25.o6lac.

Lasersohn, Peter. 2005. Context dependence, disagreement, and predicates of personal taste. Linguistics and Philosophy 28(6). 643-686. https://doi .org/10.1007/s10988-005-0596-x.

Magri, Giorgio. 2009. A theory of individual-level predicates based on blind mandatory scalar implicatures. Natural Language Semantics 17(3). 245297. https://doi.org/10.1007/s11050-009-9042-x.

Medeiros, Alessandro Boechat de. 2018. Eu acabei escrevendo o artigo - um estudo sobre a forma acabar + gerúndio no português brasileiro. Cadernos de Estudos Linguísticos 6o(1). 7-29. https://doi.org/10.20396/cel.v6o i1.8649766.

Nairn, Rowan, Cleo Condoravdi \& Lauri Karttunen. 2006. Computing relative polarity for textual inference. 67-76. https://aclanthology.org/Wo6-390 7.pdf.

Oliveira, Fátima, Luís Filipe Cunha, Sérgio Matos \& Anabela Gonçalves. 2001. Verbos de operação aspectual em PE e em PB: Semântica e sintaxe. Boletim da Abralin (26/Especial). 380-385.

Rothstein, Susan. 2004. Structuring events: A study in the semantics of aspect. Malden, MA \& Oxford: Blackwell.

Santos, Sirlei. 2014. Acabar e começar: Aspectualizadores em processo de gramaticalização. Curitiba: Universidade Federal do Paraná dissertation.

Smith, Carlota. 1991. The parameter of aspect. Dordrecht: Kluwer Academic Publishers.

Stephenson, Tamina. 2007. Judge dependence, epistemic modals, and predicates of personal taste. Linguistics and Philosophy 30(1). 487-525. https: //doi.org/10.1007/s10988-008-9023-4.

Tawilapakul, Upsorn. 2013. Counter-expectation in Thai. York: University of York dissertation.

Travaglia, Luiz Carlos. 2002. Verbos gramaticais - verbos em processo de gramaticalização. In Célia Assunção Figueiredo, Evandro Silva Martins, Luiz Carlos Travaglia \& Waldenor Barros Moraes Filho (eds.), Língua(gem): Reflexões e perspectivas, 97-157. Uberlândia: EDUFU.

Turney, Peter D. \& Patrick Pantel. 2010. From frequency to meaning: Vector space models of semantics. Journal of Artificial Intelligence Research 37. 141-188. https://doi.org/10.1613/jair.2934. 
Yalcin, Seth. 2016. Modalities of normality. In Nate Charlow \& Matthew Chrisman (eds.), Deontic modality, 230-255. Oxford: Oxford University Press. h ttps://doi.org/10.1093/acprof:oso/9780198717928.003.ooo9.

Patrícia Amaral

Department of Spanish \& Portuguese

355 North Jordan Avenue

Global and International

Studies Building 2160

Indiana University

Bloomington, IN 47405

USA

pamaral@indiana.edu
Fabio Del Prete

CLLE-ERSS UMR 5263

Maison de la Recherche

Université de Toulouse Le Mirail

5, allées Antonio Machado

31058 Toulouse Cedex 9

France

fabio.del-prete@univ-tlse2.fr 